\title{
Tafsir Al-azhar : Menyelami Kedalaman Tasawuf Hamka
}

\author{
Usep Taufik Hidayat ${ }^{1}$
}

\begin{abstract}
Abstrak
Mistisisme adalah bagian dari ilmu pengetahuan Islam yang menekankan pada nilai-nilai estetika, khususnya berbicara mengenai perilaku terhadap Tuhan dan manusia. Ketika Aisyah ditanya oleh seorang sahabat nabi Muhammad, ia berkata, "perilakunya adalah al-Qur'an". Hamka dalam tafsirnya menyatakan bahwa hal yang paling penting dalam kutipan tersebut adalah etik (akhlaq). Akhlaq merupakan bagian dari kandungan al-Qur'an yang membuat Islam tersebar di seluruh dunia. Tulisan ini menelusuri konsep Tasawuf Hamka sebagai suatu prototipe kecil dari karyanya tentang tasawuf dalam 'Tasawuf Modern.' Selain itu, tulisan ini juga fokus pada biografi Hamka serta hubungannya dengan tasawuf, metode interpretasi, rujukan utamanya, karakteristik 'Tafsir al-Azhar', metode penjulisannya, dan pendekatan yang digunakan dalam interpretasinya. Tulisan ini juga bermaksud untuk mengeksplorasi konsep uzlah, wali, mahabbah, dan ilmu ladunni in 'Tafsir alAzhar'.
\end{abstract}

Kata Kunci: Perilaku, Mistisisme, Etika, Al-Qur'an, Uzlah, Wali, Ilmu Laduni.

\begin{abstract}
The Misthycism is a part of Islamic knowledge emphases the values of estetic, especially talking about attitudes to God and the Human being. When Aisha r.a. was asked by a companion of prophet He said," His attitude is the Holy alQur'an". In his tafsir, Hamka stated that the most important thing quoted from it was ethic (akhlaq). Even it is one of the amazing of the Holy Qur'an which had spread Islam to the whole of the world. This paper will track the conception of Hamka's tasawuf as a little prototife from his work about Tasawuf at 'Tasawuf Modern'. The paper will focus in Hamka's bliography and his relate with tasawuf, the methode of interpretating, main references, characteristics Tafsir al-Azhar, methode in writing it, and the approacs used in his interpretations. Also focusing to explore conception of uzlah, sufi saint (wali), mahabbah, ilmu ladunni in 'Tafsir al-Azhar'.
\end{abstract}

Key Words: Attitudes, Mistycisme, Ethic, Amazing The Holy Qur'an, Uzlah, Wali, Ilmu Ladunni.

\footnotetext{
${ }^{1}$ Dosen STAI Al-Muhajirin Purwakarta.
} 


\section{A. Pendahuluan}

Pelacakan terhadap jejak tafsir di Indonesia diawali dengan ditemukanya manuskrip kitab tafsir Tarjuman alMustafid $^{2}$ yang kemudian diikuti oleh sekitar 151 penulisan tafsir al-Qur'an lainnya yang dianggap sempurna dan yang diketahui pada abad ke-17 sampai kepada al-Qur'an dan Tafsirnya, karya kolektif para penulis Departemen Agama Republik Indonesia di penghujung abad ke-20 ini. Ini berarti bahwa Tarjuman al-Mustafid sebagai akar geneologi dari semua literaratur tafsir pribumi yang ada sampai saat ini.

Salah satu tafsir al-Qur' an yang dihasilkan di Indonesia itu adalah Tafsir al-Azhar, karya Buya Hamka. Sebagai seorang penulis terkenal dengan khalayak pembaca yang cukup luas, Tafsir al-Azhar dengan meminjam bahasa Abdurrahman Wahid merupakan karya monumental Hamka. Lewat tafsirnya, Hamka mendemonstrasikan keluasan pengetahuannya di hampir semua disiplin yang tercakup oleh bidang ilmu-ilmu agama Islam serta

2 Tarjuman al-Mustafid telah diteliti oleh beberapa sarjana. Di antara mereka adalah Peter G. Riddel yang menyimpulkan bahwa kitab ini terjemahan dari Tafsir al-Jalalayn. Sedangkan Snouck Hurgrounje, Renkes dan Vorhoeve menyimpulkan bahwa kitab ini terjemahan dari Tafsir al-Baydawi. Namun klaim kedua kelompok tersebut disanggah oleh editor kitab ini sendiri, Antony G. Johns. Ia beralasan antara Tarjuman al-Mustafid dan Tafsir al-Baydawi jelas sekali berbeda. Dan terakhir perbedaan-perbedaan ini diteliti oleh Wahab Muhammad Salleh yang berkesimpulan bahwa kitab ini adalah karya asli. Lihat Mustafa Abdullah, "Sayyid Muhammad Rashid Ridha's Influences on Tafsir Studies in Malaysia," Middle-East Journal Science Researshes 12, no. 6 (2012) : h. 762 . pengetahuan non-keagamaan yang kaya dengan informassi. ${ }^{3}$

Menelusuri sososk Hamka memang tidak akan pernah ada habisnya. Sebagian ada yang mengatakan bahwa beliau adalah Hamzah Fansuri-nya di masa modern ini $^{4}$. Karena beliau selain seorang ulama, juga dari aspek sosial, peranan beliau begitu signifikan di tengahtengah kehidupan masyarakat muslim modern Indonesia. Dengan menunggangi kendaraan Muhammadiyyah, Hamka melanjutkan perjuangan Ahmad Dahlan sebagai pendirinya untuk fokus berdakwah melalui pendidikan dan layanan sosial masyarakat. Maka apa yang telah dilakukan olehh Fachri Ali dengan menulis sebuah artikel - yang berisi, "Hamka dan Masyarakat Indonesia: Catatan Pendahuluan Riwayat dan Perjuangannya."- sangat relevan sekali dengan sosok Hamka secara de facto. Fachri menyimpulkan bahwa Hamka adalah seorang ulama yang berada dalam posisi terdepan dalam masyarakat Islam modern Indonesia yang sedang mengalami modernisasi.

Kebesaran Hamka tidak hanya selesai di situ saja, peneliti asing yang membicarakan Hamka adalah James Rush, Karel A Steenbrink, dan Gerarrd Mousayy. Tidak jauh berbeda dengan kajian-kajian terdahulu tentang Hamka yang tidak menyinggung corak pemikiran kalamnya, maka studi Rushpun demikian pula. Ia hanya memperbincangkan Hamka dalam arti penting sebagai sebagai salah satu pelaku sejarah modern Indonesia yang

\footnotetext{
${ }^{3}$ Yunan Yusuf, Corak Pemikiran Kalam Tafsir al-Azhar, (Jakarta: Permadani, 2004), h. 6-7. Lihat juga Salman Harun, Mutiara al-Qur'an (Ciputat: Logos, 2004), cet III, h. 201.

4 Peter Riddel, Islam and The Malay Indonesian World, (Singapore: Horizon Books, 2001), h. 216.
} 
turut berperan serta membuat formulasi ide di kalangan bangsa Indonesia. Dalam paper berjudul Hamka (19081981): a Mistical Teacher as Political Leader of The Islam Indonesia, Stenbrink mencoba menyoroti peranan Hamka sebagai seorang sufi dalam kifrah politik Indonesia, semenjak zaman Jepang sampai dekat ke semenanjung akhir hayatnya.

Akhirnya di bawah judul artikel, "Une Grande Figre de L' Islam Indonesien : Buya Hamka " yang melukiskan Hamka sebagai seorang terkemuka di Indonesia. Hamka, demikian Gerrard Moussay, hanya bermodalkan pendidikan paling dasar, telah berhasil dengan caranya sendiri memperoleh pengetahuan yang sangat maju dan unggul dalam bidang yang berbeda-beda, seperti jurnalistik, sejarah, antropologi, politik, juga Islamologi. $^{5}$

Melanjutkan apa yang telah dilakukan oleh para peneliti dalam memahami Hamka. Penulis bermaksud untuk ikut serta dalam penelitian ini dengan menjadikan Tafsir al-Azhar sebagai sumber pokoknya. Adapun untuk sumber-sumber sekunder, penulis mengambil dari buku-buku beliau yang lain dan juga dari jurnal-jurnal, artikel dan sumber lain yang bersifat manuskrip maupun digital yang ada kaitannya dengan Hamka dan karyakaryanya. Kemudian juga untuk menjaga agar penelitian ini tidak panjang lebar dan fokus, maka penulis membatasi hanya dari aspek tasawufnya saja.

\footnotetext{
${ }^{5}$ Yunan Yusuf, Corak Pemikiran Kalam Tafsir al-Azhar, h. 11-12.
}

\section{B. Pembahasan}

\section{Riwayat Hidup ${ }^{6}$}

Hamka dilahirkan di kampung Molek, di sebuah desa bernama Tanah Sirah, dalam nagari Sungai Batang, di tepi Danan Maninjau, Tanjung Raya, pada tangal 13 Muharram 1362 H, bertepatan dengan 16 Pebruari 1908. Ayahnya Sheikh Abdul Karim Amrullah, adalah salah seorang yang membentuk anaknya yang kelak mengikuti jejak dan langkah yang telah diambilnya sebagai seorang ulama ${ }^{7}$.

\section{Pendidikan dan Aktivitas Hamka}

Dipanggil Abdul Malik diwaktu
bocah, Hamka $\quad$ mengawali

\footnotetext{
${ }^{6}$ Lihat juga biografi singkatnya Howard M. Federspiel, A Dictionary of Indonesian Islam, (Ohio: Center For International Studies Ohio University, 1995), h. 75.

7 Haji Rasul merupakan pendiri gerakan Kaum Muda yang berjuang mencabut akar khurafat dan bid'ah di tengah-tengah umat. Keberaniannya terlihat jelas ketika melawan Belanda. Haji Rasul ditangkap dan diasingkan ke Sukabumi. Beliau wafat di Jakarta tahun 1945. Lihat Rosnani Hashim, "Hamka Intellectual and Social Transformation of the Malay World", in Conversation Islamic Intellectual Traditionin the Malay Archipelago, ed. Rosnani Hashim, (Kuala Lumpur, Pustaka Perdana, 2010), h. 224. Selain itu untuk membaca tentang biografi Haji Rasul secara lengkap silahkan baca buku Hamka yang berjudul Ayahku yang diterbitkan pada tahun 1950. Peter Riddel, Islam and The Malay - Indonesian World, h. 216. Lihat juga Yamamoto Hiroyaki, "The Jawi Publicatio Network and Ideas Political Comunicaties Among The Malay Speaking of the Muslim 1950s", Sophia University Repository for Academic Resources, The Journal of Sophia of Student Studies, no. 27 (2009) : 062. Lihat juga Murni Djamal, DR. H. Abdul Karim Amrullah: Pengaruhnya Dalam Gerakan Pembaruan Islam di Minangkabau pada Awal abad ke-20 (LeidenJakarta: Hak Cipta INIS, 2002), h. 20.
} 
pendidikannya dengan membaca alQur'an di rumah orang tuanya ketika mereka sekeluarga pindah dari Maninjau ke Padang Panjang pada tahun 1914. Dan setahun kemudian setelah mencapai usia tujuh tahun Abdul Malik -Hamka kecil- itu dimasukkan ayahnya ke Sekolah Desa. ${ }^{8}$ Pada usia delapan sampai lima belas tahun, pendidikan agama Hamka masih berbasis pendidikan di lingkungan keluarga. Terutama kepada ayahnya, Hamka ditekankan untuk mengikuti jejak dan pemikirann ayahnya. Pada fase pendidikan agama yang ilmiah dan bervariasi inilah yang kemudian menjadi faktor utama menjadikan Hamka melakukan praktek ibadah dan membudayakan pemikirannya 9 .

Pada tahun 1916, ketika

Zainuddin Labai el-Yunusi mendirikan sekolah Diniyyah petang hari, di Pasar Usang Padang Panjang, Hamka lalu dimasukkan oleh ayahnya ke sekolah ini. Pada tahun 1918 di saat Abdul Malik, si Hamka kecil itu, sudah di khitan di kampung halamnnya, Maninjau dan di waktu yang sama ayahnya, Sheikh Abdul Karim Amrullah kembali dari perlawatan pertamanya ke tanah Jawa, Surau Jembatan Besi, tempat Sheikh Abdul Karim Amrullah memberikan pelajaran agama dengan sistem lama diubah menjadi madrasah yang kemudian dikenal dengan Tawalib School. ${ }^{10}$

\footnotetext{
${ }^{8}$ Yunan Yusuf, Corak Pemikiran Kalam Tafsir al-Azhar, h. 40.

9 Peter Riddel, Islam and The Malay Indonesian World, h. 216.

${ }^{10}$ Dengan adanya perubahan metode dari surau ke madrasah ini, intelektual agama masyarakat Minangkabau bertambah baik secara cepat. Hal tersebut disebabkan karena madrasah tidak hanya mempelajari al-Qur'an saja, tetapi juga sebagai institusi pendidikan yang sukses memproduksi cendikiawan sekaliber Palimo Kayo, Buya Hamka, A.R. Sutan Mansur, Muhammad Natsir, Bey
}

Pada tahun 1924 Hamka berangkat ke Jawa. Kota tujuan pertamanya adalah kota organisasi pembaharu Muhammadiyyah, Yogyakarta. Hamka mendapatkan kesempatan mengikuti kursus-kursus yang diselenggarakan oleh Muhammadiyyah dan Syarikat Islam. Di kota ini Hamka bertemu dengan $\mathrm{Ki}$ Bagus Hadikusumo belajar tafsir alQur'an. Ia bertemu dengan HOS Cokroaminoto, dan mendengar ceramahnya tentang Islam dan Sosialisme. Serta juga bertukar pikiran dengan Haji Fakhruddin, Syamsul Rizal, tokoh Jong Islameten Bond.

Selanjutnya ia melanjutkan pengembaraannya ke Pekalongan selama lebih kurang enam bulan dan bertemu A.R. Sutan Mansur, ${ }^{11}$ menantu ayahnya yang menetap di Pekalongan. Pada usia 16 tahun, Hamka telah berpidato di mana-mana dengan jiwa dan semangat kesadaran baru itu. Pada usia 17 tahun ia telah kembali ke tanah minang, ia tumbuh menjadi pemimpin di lingkungannya. Aktivitasnya sebagai orang pergerakan - yang telah tertanam dalam jiwanya sejak tinggal di Yogyakarta membuat Hamka tidak tingal diam di Tanah Suci. Sesudah ia berangkat dari tanah air pada Februari 1927, bersama beberapa calon jemaah lainnya ia mendirikan organisasi Persatuan Hindia terutama manasik haji,

Arifin dan lain-lain. Lihat Rosnani Hashim (ed), “ Reclaiming Conversation Islamic Intellectual Traditionin the Malay Archipelago”, Kuala Lumpur : Pustaka Perdana, 2010), h. 207.

11 Menurut Azyumardi Azra, A.R. Sutan Mansur bersama dengan Buya Abdullah Ahmad, Haji Rasul (ayah Buya Hamka) dan Hamka sendiri adalah tokoh-tokoh minang yang pemikirannya berorientasi Islam. Sedangkan sepeninggal mereka, intektualitas tokoh Minang sudah bercampur dengan pemikiran Barat. Azyumardi Azra, Islam Substanstif: Agar Umat Tidak Jadi Buih, (Mizan: Bandung, 2000), h.114. 
kepada calon jema'ah haji asal Indonesia.

Ketika kongres Muhammadiyyah ke-19 yang berlangsung di Bukit Tinggi pada tahun 1930, Hamka tampil sebagai presentator dengan makalah berjudul Agama Islam dan Adat Minangkabau. Lalu pada kongres ke20 di Yogyakarta tahun 1931, lagi-lagi Hamka muncul dengan ceramah berjudul Muhammadiyah di Sumatra. Tahun 1933 ia mengikuti muktamar Muhammadiyah di Semarang. Dan pada tahun 1934, ia diangkat menjadi anggota majlis Konsul Muhammadiyah di Sumatera Tengah.

Tahun 1935 mendirikan Kuliyyatul Muballighin. Namun pada tahun itu juga beliau harus ke Makassar karena kehadirannya sangat dibutuhkan dalam misi pembuatan karya tulis. Beliau tinggal di sana selama tiga tahun. Sementara beliau di Makasar, beliau menulis untuk surat kabar yang beredar di Medan dan Jakarta. ${ }^{12}$ Tahun 1936 beliau pindah ke Medan. Di kota ini Hamka pindah bersama M Yunan Nasution menerbitkan majalah Pedoman Masyarakat, majalah yang tidak kecil memuat andil bagi kepengarangan dan kepujanggaan Hamka. Seperti Di Bawah Lindungan Ka'bah, Pedoman Muballigh Islam, Lembaga Hidup, Lembaga Budi, Tenggelammnya Kapal Van Der Wijk ${ }^{13}$,

${ }^{12}$ Menurut tulisan Yunan Yusuf, pada tahun 1936 beliau pindah ke Medan. Pendapatnya ini ini berarti bertentangan dengan apa yang didapatkan dari data yang ada dibuku ini. Namun, hemat penulis, Yunan Yusuf di sini mendapat misunderstanding dari informasi yang beliau dapatkan. Faktanya pendapat yang pertama lebih bisa diterima akal, karena memang Hamka tinggal di Makasaar namun beliau sering bolak balik Makasar - Medan. Lihat Rosnani Hashim (ed), "Hamka Intellectual and Social Transformation of the Malay World", h. 226.

13 Buku ini sukses di negara-negara berbahasa Melayu, terutama Indonesia, Malaysia,
Tasawuf Modern ${ }^{14}$, Falsafah Hidup, Merantau ke Deli, dan Tuan Direktur ${ }^{15}$. ${ }^{16}$ Majalah Pedoman

Brunei dan Singapura. Ceritanya juga telah dijadikan skenario sebuah film. Buku novel ini pernah dituduh oleh pihak PKI yang dimotori Aidit sebagai plagiat. Waktu itu berbarengan dengan jatuhnya Masyumi dan desakan agar HMI dibubarkan. Lihat Muhammad Hilmi Jalil dan Fakhrul Adabi Abdul Kadir, "Written Works As A Channel of Human Development : Studies On Hamka's Novel", IJRESS 2, no.5 (Mei 2012) :2. Lihat juga Azyumardi Azra dan Saiful Umam (ed), Mentri-Mentri Agama RI : Biografi Sosial Politik, h. 234.

${ }^{14}$ Sebelum Hamka, cendikiawan muslim dunia yang kreatif merekonstruksi Tasawuf secara modern adalah Sir M. Iqbal (1873-1938 M). Iqbal menyerap pemikiran al-Hallaj tentang jiwa yang dinamis yang dibangun dengan teori modern. Iqbal menolak segala aspek Sufisme yang dipandangnya negatif, fatalisme, pasivitas dan pemahaman yang keliru dalam peleburan hamba dengan TuhanNya. Lihat Carl W. Ernst, Ajaran dan Amaliah Tasawuf (Jogjakarta: Penerbit Pustaka Sufi, 2003), h. 262. Penulis berasumsi bahwa latar belakang Tasawuf Modern ini mungkin karena pada masa Hamka kebutuhan akan spritual semakin meningkat. Kekeringan spiritual sudah sangat terasakan oleh Hamka. Selain itu juga, untuk mengimbangi merebaknya pemikiran Islam dari luar terutama dari Timur Tengah. Pemakaian akal dalam bereksplorasi nilainilai Islam harus diimbangi dengan peranan instusi (dalam buku Tasawuf Modern, Hamka menyebut instuisi dengan khayal). Dan memang ketertarikan masyarakat terhadap Tasawuf mulai tumbuh kembali pada masa Hamka. Fred R. Von der Mehden, Islam in Indonesia in The Trwenty-First Century, in Asian Islam in the 21st Century, (New York: Oxford University Press, 2008), h. 13.

${ }^{15}$ Menurut Rosina Hashim urutan karya-karya Hamka yang berhasil ditelusuri berdasarkan tahun adalah Tasawuf Modern, Falsafah Hidup, Lembaga Hidup dan Lembaga Budi. Kemudian diikuti oleh Di Bawah Lindungan Ka'bah dan Tenggelamnya Kapal Van Der Wijck. Lihat Rosnani Hashim (ed), "Hamka Intellectual and Social Transformation of the Malay World", h. 226.

${ }^{16}$ Yunan Yusuf, Corak Pemikiran Kalam Tafsir al-Azhar, h. 48-49. 
Masyarakat ini dibekukan untuk sementara selama perang dunia kedua dan karena kesibukan Hamka dalam organisasi Muhammadiyyah di Sumatera Barat. Selanjutnya pasca perang kedua pada tahun 1945, Hamka kembali ke Padang Panjang. Antara tahun 1945-1949 beliau ditunjuk sebagai sekretaris untuk Front Pertahanan Nasiona (PETA) sebagai partai politik yang menguasai di Sumbar untuk melawan Belanda yang diketuai oleh M. Hatta. Kemudian Hamka membentuk Badan Pembela Negara dan Kota (PBNK) yang merupakan gerakan masyarakat gerilyawan terbesar dalam melawan Belanda. Selama posisinya tersebut Hamka tidak pernah tinggal di satu kota dalam jangka waktu yang lama ${ }^{17}$.

Pasca kemerdekaan, Hamka tinggal di Jakarta dan meneruskan aktivitas menulis literatur dan budayanya. Beliau mengikuti pemilu tahun 1955 di bawah partai Islam Masyumi dan terpilih sebagai anggota Dewan Konstituante. Beliau menemukan adanya gerakan komunis secara terbuka dan menyebarkan paham ateis di tengah-tengah masyarakat. Pada tahun 1959, partai Masyumi dibubarkan oleh Sukarno karena kemajuan di Sumbar melibatkan para pemimpinnya. Selain Hamka, diantaranya M. Natsir dan Syafruddin Prawiranegara. Kemudian Hamka melanjutkan aktivitasnya dalam menulis dan menerbitkan majalah Panji Masyarakat yang berorientasi dakwah dan kultur Islam.

Kemudian beliau menjadi Imam Besar Masjid al-Azhar, Kebayoran Baru serta aktif memberikan Kuliah Subuh dan Tafsir al-Qur'an . Pada tanggal 27 Agustus 1964, beliau dipenjara dengan

\footnotetext{
${ }^{17}$ Rosnani Hashim (ed), "Hamka Intellectual and Social Transformation of the Malay World", h. 226.
}

alasan telah melakukan Subversiv. Majalah Panji Masyarakat dihentikan karena menerbitkan artikel M. Hatta yang mengkritik Sukarno. Namun hal tersebut malah menjadi berkah bagi Hamka karena di dalam sel beliau melanjutkan untuk menulis Tafsir alAzhar. Dan pada saat yang sama tafsirnya diterbitkan oleh Malaysia. ${ }^{18}$ Beliau sering diundang untuk mengisi seminar di organisasi, lembaga dan badan-badan hukum yang ada di sana. Yang akhirnya berbuah terhadap pemberian Honoris Doctor of Letters dari Universitas Kebangsaan Malaysia (UKM) pada tahun 1974. Beliau menyampaikan orasi ilmiah yang berbicara tentang kebesaran Melayu dan hubungannya dengan Islam.

Pada tahun 1975, Hamka ditawari menjadi ketua MUI oleh Menteri Agama. Dalam pidato penerimaanya beliau mengingatkan agar para pemimpin memperhatikan keseimbangan terutama perkembangan spiritual. Beliau bisa memberikan saran kepada pemerintah dan mengatur posisinya. Namun demikian, beliau cenderung untuk terjun ke dalam politik selama lima tahun dan bersebrangan dengan pemerintah yang membolehkan natal bersama. Beliau meninggal tahun 1981 pada bulan Ramadhan. ${ }^{19}$

Pada zaman Soekarno kelompok Islam ini ada yang ditemani ada yang di musuhi. Strategi tersebut adalah politik belah bambu. Yang satu diinjak dan satunya lagi diangkat. Kelompok yang diinjak adalah kelompok Islam modernis - kelompok Masyumi yang dimotori Muhammad Natsir. Sedangkan yang diangkat adalah kelompok NU

\footnotetext{
${ }^{18}$ Rosnani Hashim (ed), "Hamka Intellectual and Social Transformation of the Malay World", h. 227.

19 Rosnani Hashim (ed), "Hamka Intellectual and Social Transformation of the Malay World", h. 227.
} 
yang selanjutnya menjadi salah satu poros Nasakom. Buya Hamka dan banyak tokoh modernis banyak yang dipenjarakan. $^{20}$

\section{Karakter Khas Sosok Hamka}

Dalam bagian ini penulis sengaja menelusuri sifat-sifat yang melekat pada sosok besar Hamka. Hal ini sangat beralasan, mengingat Hamka terkenal sebagai sosok yang sukses dalam lisan dan tulisan. Beliau juga orang yang supel bergaul di masyarakat. Penanya setajam pedangnya. Namun lisan beliau, dalam konotasi positif, lebih tajam lagi. Beliau sering disebut Singa Podium. Penulusuran terhadap karakter beliau yang terdapat dalam tulisan yang membahas biografi beliau ini bisa dijadikan acuan untuk mengetahui corak dan karakter tafsir yang beliau tulis dan menjadi objek pokok dalam penelitian ini.

Salah satu karakter khusus dari Hamka, menurut Azra, adalah komitmennya yang kuat untuk memegang pendirian. Apabila ada

20 Azyumardi Azra, Islam Substansif: Agar Umat Tidak Jadi Buih, h. 320. Selain Hamka, tokoh muslim sekaligus politisi yang dipenjarakan adalah Natsir, Roem, Prawoto, Sutan Syahrir. Sementara itu Rasyidi mendengar berita tersebut ketika di Montreal dan ketika itu juga langsung pindah ke Washington. Penulis mengkaitkan Hamka dengan Rasyidi karena keduanya sezaman dan mempunyai pemikiran yang sama tentang Islam. Beda antara keduanya, Hamka dilihat masyarakat sebagai pujangga dan ulama. Sementara Rasyidi sebagai generasi intelektual. Lihat Endang Basri Ananda (Penyunting), 70 Tahun Prof. Dr. H.M. Rasyidi (Jakarta: Harian Umum Pelita, 1985), h. 66, h. 227. Lihat juga Azyumardi Azra dan Saiful Umam (ed), Mentri-Mentri Agama RI: Biografi Sosial Politik, (Jakarta: IndonesiaNetherland Cooperation in Islamic Studies (INIS), Pusat Pengkajian Islam dan Masyarakat (PPIM), Badan Litbang Agama Depag RI, 1998), h. 148. masalah agama atau negara yang bertentangan dengan persfektif Hamka berdasarkan norma agama maka ia akan menjadi oposisi. Ia jadikan posisi ini juga kekuatan untuk membangun agama dan negara dari arah luar. Sebagai contoh sikap Hamka yang mengundurkan diri karena tidak sepaham dengan pemerintah Soeharto. ${ }^{21}$ Sikap ini selanjutnya ternyata diikuti juga oleh KH. Ali Yafie, yang mengatakan mundur sebagai ketua MUI karena melihat kebijakan-kebijakan Gus Dur yang tidak akseptabel. ${ }^{22}$

Namun terkadang Hamka juga berpendirian yang melawan arus. Bukan berarti pendiriannya ini dalam konotasi positif. Hamka secara mental siap menerima cela, kritik dan makian dari mayoritas umat Islam Indonesia. Salah satunya adalah ketika pemerintah Jepang mewajibkan rakyat Indonesia untuk tunduk kepada kekuasaan Jepang di Tokyo. Hamka dan pengikutnya diminta datang menghadap pada tanggal 29 April 1942 dengan paksa untuk tunduk kepada kekuasaan Jepang. Harihari tersebut merupakan masa tersulit bagi kaum muslimin Indonesia. ${ }^{23}$

\footnotetext{
${ }^{21}$ Pokok masalahnya adalah bahwa Hamka tidak setuju dengan Menteri Agama Alamsyah yang meminta MUI untuk mencabut fatwa yang mengharamkan Natal bersama sebagai respon dari SK Menag No.35 tahun 1980 yang ditetapkan 30 Juni 1980. Azyumardi Azra dan Saiful Umam (ed), Mentri-Mentri Agama RI: Biografi Sosial Politik, 341. Lihat juga Alwi Shihab, Membendung Arus: Respons Gerakan Muhammadiyyah Terhadap Penetrasi Misi Kristen di Indonesia, (Bandung: Mizan, 1998), h. 181.

22 Azyumardi Azra, Islam Substanstif : Agar Umat Tidak Jadi Buih, h. 385.

${ }^{23}$ Goto Ken'ichi, "Modern Japan and Indonesia The Dynamics and Legacy of Wartime Rule", Leiden, Bijdragen tot de Taal-, Land- en Volkenkunde, Japan, Indonesia and the WarMyths and Realities 152, no: 4 (1996) : h. 536-552.
} 
Zulkifli (1966) mengatakan bahwa Hamka mempunyai sikap tegas dalam menyikapi isu Shi'ah. Dalam menyikapi isu Shi'ah yang sejak masa ulama salaf (setelah abad ke-2 H) selalu diposisikan sebagai pihak yang bersebrangan dengan Sunni. Hamka menilai bahwa jaringan yang pertama memasukkan Islam justru dari kaum Sunni dan untuk selanjutnya meneruskan dominasi tersebut sampai saat ini. ${ }^{24}$ Akan tetapi hal tersebut bukan berarti Hamka menolak peranan Shi'ah secara mutlak. As'ad Shahab adalah orang yang mengenalkan kepada Hamka berbagai buku-buku Shi'ah yang menunjukan penerimaan Hamka terhadap literatur Shi'ah. Dalam tafsirnya, Hamka mengutip beberapa kitab, diantaranya Tafsir al-Mizan karangan al-Taba'taba'i dan al-Bayan fi Tafsir al-Qur'an al'Adim karya Ayatullah al-Kha'is. ${ }^{25} \mathrm{Hal}$ ini menunjukan bahwa Hamka sangat toleran dalam keilmuan. Jargon kembali kepada al-Quran dan al-Sunnah telah memberikan pemahaman kepadanya bahwa selama semua karya ilmiah masih di bawah koridor keduanya, maka tidak ada alasan untuk menolaknya.

\section{Karya-karya}

Hamka termasuk penulis yang sangat produktif dan menghasilkan lebih dari 76 buku. Sumber lain ada yang mengatakan 50 buku. ${ }^{26}$ Karyakarya Hamka ini sangat populer di

\footnotetext{
${ }^{24}$ Zulkifli, The Strugle the Shi' $i$ In Indonesia (Leiden : University of Leiden, 2009), h. 11.

${ }^{25}$ Zulkifli, The Strugle the Shi'i In Indonesia', h. 34.

${ }^{26}$ Zulami Ya'kub, "Falsafah Alam dan Konteks Falsafah Ketuhanan Menurut Hamka," International Journal of Islamic Thought 1 (June 2012) : h. 2. Lihat juga Samsul Nizar, Memperbincangkan Dinamika Intelektual dan Pemikiran HAMKA tentang Pendidikan Islam (Jakarta: Kencana, 2008), h. 46.
}

masyarakat khususnya di kampus. Isi dari buku-buku Hamka terdiri dari cerita-cerita roman, kritikan-kritikan sosial dan politik sampai kepada ilmuilmu agama.

Salah satu keahlian Hamka yang tidak dimiliki oleh ulama lain adalah penguasaannya tentang sejarah Islam. Melalui bukunya Sejarah Umat Islam $^{27}$

${ }^{27}$ Salah satu penelitian Hamka yang banyak dijadikan rujukan adalah keberhasilannya menentukan bahwa Islam masuk ke Indonesia pada awal abad ke-8 atau lebih tepatnya adalah abad ke-7. Islam di Indonesia berhubungan dengan Arab lebih dulu dari pada India. Bukti sejarah yang paling nyata adalah ditemukannya perkampungan Arab tahun 674 M di pantai Barat Sumatra dan di Kalingga, pada masa Ratu Sima yang keduanya bersumber dari berita China. Penelitiannya ini sejalan dengan para intelektual muslim tahun 1980-an yang sepakat untuk rekonstruksi sejarah komunitas Islam Indonesia. Di antara mereka adalah Roeslan Abdul Ghani, Taufik Abdullah, Hasan Mu'arif Ambary, dan A. Hasyimi. Pandangan Hamka secara khusus tentang teori awal masuk Isslam ke nusantara ini lebih dapat diterima dengan alasan lebih tajam dalam penelitiannya dibandingkan peneliti dari Barat dan Orientalis. Objek penelitian dalam hal ini, Hamka sampai meneliti tentang Madzhab Fiqih yang dianut ketika itu oleh para da'i dan hal ini merupakan isi laporan dari perjalanan Ibnu Batutah. Teori Hamka ini kemudian diamini oleh KH. Syaifuddin Zuhri. Lihat Ota Atsushi, Okamoto Masaaki, dan AhmadSuaedy (ed), Islam In Contention: Rethinking Islam and State in Indonesia (Jakarta: Wahid Institute - CSEAS-CAPAS , 2010), h. 333. Lihat juga Ahmad Mansyur Suryanegara, Menemukan Sejara : Wacana Pergerakan Islam di Indonesia, (Bandung : Mizan, 1998), Cet IV, h. 81-84, 94, 97. Keahlian Hamka dalam sejarah bahkan lebih spesifik lagi kepada pemahamannya yang dalam tentang Tasawuf. Beliau paham sekali dengan jaringan ulama Nusantara, Tariqat Idrisiyyah, Yusuf al-Maqassari dan pengembaraannya yang tertuang dalam bukunya Sjech Yusuf Tadju'l Chalwati (Tuanku Salamaka). Bukunya Perbendaharaan Lama meunjukkan bahwa beliau sangat dalam pemahamnnya tentang warisan, atsar, jejak, petuah yang diwariskan 
(1977), Hamka menulis tentang sejarah Islam dengan sistimatika periode berkuasa masing-masing kerajaan. Dalam karyanya ini beliau menekankan akan pereanan raja dan kerajaanya yang pernah menguasai nusantara ini. Hamka juga yang mengenalkan buku-buku sejarah Indonesia klasik seperti Sejarah Melayu (Malay History) $^{28}$ oleh Tun Sri Lanang; Hikayat Raja-raja Pasai (Tale of Pasai Kings) oleh Sheikh Nur al-Din arRaniry; Tuhfat al-Nafis (the Precious Gift) oleh Raja Ali Haji; Sejarah Cirebon (History of Cirebon), Babad Giyanti (Tale of Giyanti) dan lain-lain. ${ }^{29}$

\section{Cak Nur kagum dengan Buya Hamka}

Awal tumbuhnya intelektual di Indonesia ternyata sudah bersporadis sejak zaman kerajaan Hindu Kediri atau

para ulama dan tokoh tempo dulu. Dikutip dalam footnote Azyumardi Azra, Jaringan Ulama Timur Tengah dan Kepulauan Nusantara Abad VII dan VIII, (Jakarta: Kencana, 2013), h. 274.

28 Asumsi penulis melalui buku ini, orang Malaysia berhutang kepada Hamka berupa informasi nenek moyang mereka, demikian pula Hamka berhutang kepada masyarakat Malaysia atas penerimaan mereka secara luas terhadap sosok Hamka. Hamka pernah mengusulkan agar bahasa Melayu menjadi identitas bangsa Indonesia dan menjadi sumber kekuatan dan kesatuan. Hamka sangat fanatik dengan isu-isu agama dan selalu berusaha mendefinisikan pemecahan masalahnya dengan menghubungkan antara Islam dan Melayu. Lihat Rosnani Hashim (ed), "Conversation Islamic Intellectual Traditionin the Malay Archipelago (Kuala Lumpur: Pustaka Perdana, 2010), h. 32.

${ }^{29}$ Sulasman, "Kyai and Pesantren in the Islamic Historiography of Indonesia," International Journal for Historical Studies 4, no.1 (2012) : 67, h. 71-72. Tema-tema yang diusung oleh Hamka dalam bukunya ini ditulis berdasarkan dengan tema-tema yang ditulis dalam bukubuku sejarah pada umumnya. Sistematika penulisannya tidak mengalami variasi perubahan. kerajaan Dhaha. Rajanya yang terkenal adalah Jayabaya. Selain sebagai raja, Jayabaya juga mempunyai hobi menulis yang dibuktikan dengan peninggalannya berupa karya tulis yaitu Jangka Jayabaya. Ternyata, berdasarkan sejarah Islam beliau sejaman dengan alGhazali.

Berbicara tentang intelektual Indonesia, menurut Cak Nur bahwa tokoh ayng mewariskan tradisi intelektual yang cukup signifikan dan berpengaruh terhadap corak keagamaan Indonesia (pen.) hanyalah Hamzah Fansuri, Nuruddin al-Raniri, Syeikh Nawawi al-Bantani, Kiyai Ihsan Muhammad Dahlan al-Jampesi, Kediri, dan Hamka. ${ }^{30}$ Menurutnya, selain yang

${ }^{30}$ Menurut Kul (2005), perhatian masyarakat muslim Indonesia yang diajarkan Nurcholis Majid sejak tahun 1990-an melalui Yayasan Paramadina itu lebih banyak dan berhasil membangkitkan potensi spiritual mereka dari pada pencapaian yang diperoleh Hamka melalui buku Tasawuf Modern. Hal ini merupakan sikap antara dua cendikiawan muslim yang berbeda pemikirannya tentang Islam, namun Nurchalis Majid tidak egoisme untuk tidak mengambil pelajaran kepada Hamka. Bahkan beliau mneruskan usaha Hamka dalam mengajarkan nilai Tasawuf kepada masyarakat muslim Indonesia. Lihat Martin Van Bruinessen and Julia Day Howell (ed), "Sufisme and Modern In the Islam" (London and New York, I.B. Tauris 2007), h. 241. Menurut penelitian Ahmad, Hamka termasuk tokoh Islam Indonesia yang menonjol dalam bidang Filsafat yang sangat memperhatikan akan hubungan etnik di Indonesia. Tetapi menurut penulis, bukan berarti Tasawuf yang diusung Hamka adalah Tasawuf Falsafi yang disuarakan oleh Ibnu Arabi, akan tetapi beliau cenderung kepada Tasawuf Akhlaki yang diusung oleh Junaid al-Baghdadi dan al-Ghazali (w. $1111 \mathrm{M} / 505$ H) Lihat Rooasfa Hashim, "Ethnic Relation: Some Related Editorial Issues", Malaysia, Medwell Journal: The Social Science 7, no. 4 (2012) : h. 557-559. Menurut Roshina Hashim, Hamka bersama dengan Munshi Abdullah, Shaykh Ahmad al Hady and Za'ba of Malaya (Peninsular Malaysia), dan Sheikh Abd al-Samad al-Palimbani, Imam Zarkasyi, 
disebutkan tadi, pada umumnya tradisi intelektual Islam kita masih menghasilkan karya-karya yang terbatas pada hal-hal elementer, bukan pemikiran dan perenungan mendalam. ${ }^{31}$ Cerita lain, menurut Cak Nur, yang menunjukkan ketinggian intelektualitas Hamka adalah perumpamaan beliau terhadap Pancasila. Menurut Hamka, Pancasila bagaikan bilangan 10.000. Dimana angka 1 (satu) merupakan perumpamaaan sila Ketuhanan Yang Maha Esa. Sedangkan bilangan nol yang jumlahnya ada empat diumpamakan sebagai sila kedua sampai kelima. Maka apabila dihilangkan angka satunya, bilangan empat nol yang ada setelahnya menjadi tidak ada nilainya walaupun ditambah lagi dengan deretan nol yang panjang. ${ }^{32}$ Zuriati (2010) menambahkan tentang kelebihan Buya Hamka. Menurut pandangnnya, Buya Hamka (w. $1981 \mathrm{M}$ ) selain mengayomi internal Islam, beliau juga pandai berdiplomasi dengan agama lain. Beliau bersamasama dengan Isma'il al-Faruqi (w. 1986 M) termasuk cendikiawan muslim yang meneruskan tongkat estafet keilmuan perbandingan agama (Comperative Religion). Hamka mempunyai kontribusi yang tidak sedikit dalam

Mahmud Yunus, Harun Nasution and Hasyim Asy'ari termasuk ke dalam pemikir pendidikan. Lihat Rosnani Hashim (ed), Reclaiming the Conversation: Islamic Intellectual Tradition in the Malay Archipelago, (Malaysia: Pustaka Perdana, 2010), h. 28.

${ }^{31}$ Nurcholis Majid, Tradisi Islam (Peran dan Fungsinya Dalam Pembangunan di Indonesia, (Dian Rakyat dan Paramadina : Jakarta, 2008), h. 5.

${ }^{32}$ Nurcholis Majid, Islam Kemodernan dan Keindonesiaan, (Bandung: Mizan, 1998), cet XI, h. 178 bidang yang disebut dengan Religionswissenschaft. ${ }^{33}$

\section{Tafsir al-Azhar : Tela'ah Khusus}

Tafsir al-Azhar mulai ditulis pada tahun 1962. Tafsir ini melukiskan dengan gamblang Hamka dalam suasana kuliah di pagi hari yang ia sampaikan pada tahun 1959 sampai 1964 di masjid al-Azhar, Jakarta. Penulisan tafsir ini sempat ditulis di penjara selama tiga tahun, yaitu 19641966. Beliau di penjara pada rezim Sukarno, karena pengaruhnya meluas sangat mengganggunya dan dianggap sebagai potensi adanya oposisi. Ujianujian hidupnya, beliau kemukakan pada bab $12 .{ }^{34}$ Tafsir ini sebanyak 15 volume bersama dengan novel-novel karya beliau telah memperoleh minat dari pembaca bahkan telah menjadi standar buku bacaan di seluruh jalan di Singapura dan Malaysia.

\section{Isi Mukjizat al-Qur'an Menurut Hamka}

Menurut Hamka mukjizat alQur'an itu adalah al-Qur'an itu sendiri. Namun, Secara lebih spesifikasi lagi, kemukjizatannya dapat diringkas menjadi tiga. Pertama, keistimewaan yang pernah dicapai oleh bangsa Arab, yang kedua ialah makna atau ma'aninya dan yang ketiga adalah ajaran akhlaknya. Yang dimaksud ajaran akhlak di sini bukanlah ajaran agama, akan tetapi puncak budi dari manusia yang cerdas, dan tidaklah dapat dibantah bahwa itulah akhlak yang baik. Untuk yang ketiga ini merupakan hal yang jarang menjadi perhatian para

\footnotetext{
${ }^{33}$ Zuriati ibn Muhammad Rashid, "Al-Faruqi and His Views on Comparative Religion, "International Journal of Business and Social Science 1, no. 1 (2010) : h. 1.

34 Peter Riddel, Islam and The Malay Indonesian World, h. 218.
} 
mufassir. Umumnya mereka melihat dari sisi dzahir al-Qur'an saja. ${ }^{35}$

\section{Latar Belakang ditulis Tafsir al-Azhar dan penamaannya}

Hukum kausalitas mengatakan "setiap adanya aksi selalu diikuti dengan reaksi". Hukum tersebut menggambarkan akan karakter khas yang dimiliki oleh setiap makhluk hidup bukan hanya manusia. Suatu karya yang besar, biasanya selain sudah dirancang secara matang, ia juga dihasilkan karena adanya suatu faktor X. Biasanya latar belakang dihubungkan dengan seberapa cepatkah respon yang dimiliki dan umumnya karya yang mempunyai latar belakang nilai sejarah yang mengikuti kemunculannya suatu karya berpengaruh. $\quad \mathrm{Di}$ dalam pendahuluannya, Hamka dengan tawadhu mengakui bahwa beliau bukanlah seorang yang multidisiplin.

Beliau mengakui bukan seorang pakar gramatika Arab, bukan pakar sastra Indonesia (padahal beliau sudah menulis karya tulis dengan bahasa Indonesia sebanyak 100 buku besar dan kecil di dalam bahasa Indonesia, bukan insinyur pertaniann dan bukan ahli atom. Namun persyaratan tersebut tidak menghalanginya untuk melanjutkan penafsirannya. Menurutnya, ada soal lain yang sangat mendesak yang menjadikan alasannya mempertahankan tafsirnya. Alasan tersebut adalah bangkitnya minat kawula muda untuk mengkaji al-Qur'an di Indonesia dan di negara-negara yang berbahasa Melayu.

Beliau menganalogikan keadaan mereka ini dengan perumpamaan rumah telah kelihatan, jalan ke sana tidak ada. Ini adalah alasan pertama menulis kitab ini. Kedua, tafsir al-Azhar

\footnotetext{
35 Hamka, Tafsir al-Azhar, (Jakarta: Citra Serumput Padi, 1982), juz I, h. 12.
}

disusun untuk golongan para muballigh atau ahli dakwah. Mereka kadang canggung untuk tampil, karena wawasan umumnya sangat lemah. Pada hal mereka mempunyai kewajiban sudah lebih luas dari pada muballigh zaman lampau. Sekarang mereka menghadap bangsa yang cerdas.

Rosnani Hashim menyimpulkan penelitiannya bahwa latar belakang yang menyetir Hamka untuk menulis Tafasirnya adalah adanya kevakuman pada golongan pemuda di negara-negara yang berbahasa Melayu, dan adanya kehausan dari mereka terhadap pemahaman agama, terutama al-Qur'an. Serta adanya kelemahan materi-materi yang disampaikan oleh para mubaligh. ${ }^{36}$

\section{Haluan Tafsir}

Sebelum menyampaikan penelitian sendiri Roshani Hashim meneliti bahwa sumber Tafsir al-Azhar ini meliputi kitab-kitab tafsir klasik yang terdiri dari tafsir kalangan Sunni, Mu'tazilah dan Syi'ah. Selanjutnya dalam pembahasan awal dalam bab ini. Hamka menyatakan secara eksplisit tentang corak haluan dari penafsirannya. Beliau memberikan istiah sendiri yaitu "textbook thinking". Yaitu suatu tafsir yang hanya menuruti riwayat atau naql dari orang terdahulu saja. Sebaliknya dari itu terkadang seorang mufasir dalam menjelaskan perihal agama ngelantur kemana-mana, sehingga tidak disadari telah menjauh dari maksud agama. ${ }^{37}$

\footnotetext{
${ }^{36}$ Rosnani Hashim, "Hamka: Intellectual and Social Transformation of the Malay World", in Reclaiming the Conversation: Islamic Intellectual Tradition in Malay Archipelago , ed. Rosnani Hashim, (Kuala Lumpur: Perdana Leadership Foundation, 2010) : h. 194.

${ }^{37}$ Sehubungan dengan penafsiran yang berteletele, Sayyid Qutub menjelaskan bahwa keterangan yang terlalu panjang dan berbelitbelit akan menghalangi nur dan inspirasi al-
} 
Sebagaimana dijelaskan oleh Hamka bahwa tafsir itu membaca corak pandangan si mufassir dalam haluan madzhabnya. Sehinga kadang-kadang al-Qur'an yang begitu terang dipersempit oleh penafsir itu sendiri, dibawa ke haluan yang ditempuhnya. Sebagai contoh, al-Zamakhshari dalam al-Kashshaf, beliau membela madzhab kalam yang beliau anut, yaitu Mu'tazilah. Al-Razi cenderung membela madzhab Shafi'ii yang dibelanya. Dan al-Alusi dalam Ruh alMa'ani membela madzhab Hanafi, padahal dulu ia membela madzhab alShafi'i.

Oleh alasan demikian, beliau menulis tafsir ini tanpa membawa pertikaian-pertiaian madzhab karena beliau tidak ta'assub (fanatik) terhadap suatu faham. ${ }^{38}$ Tafsirnya berhaluan

Qur'an terhadap pembaca atau orang yang ingin menafsirknnya. Bahkan keterangan yang panjang ini akan merubah tujuan pendidikan tafsir kepada ensiklopedi ilmu pengetahuan khilafiyah. Keterangan yang panjang akan menghalangi keindahan alQur'an berdasarkan pengalamnnya ketika masih kecil. Shalah Abdul Fattah al-Khalidi, Tafsir Metodologi Pergerakan, (Jakarta: Yayasan Bunga Karang, 1986), h. 79.

${ }^{38}$ Beberapa contoh tidak adanya fanatisme buta pada diri Hamka ditunjukkan ketika beliau bersama dengan KH. Abdullah Syafi'i, seorang kiyai Betawi pendiri Yayasan AsySyafi'iyyah, Pondok Gede. Dalam suatu kesempatan shalat Jum'at digelar di Masjid al-Azhar. Tradisi di mesjid ini adzan dilakukan sekali saja. Sebenarnya khatib pada kesempatan itu giliran Buya, namun karena kedatangan tamu Adullah Syafi'i beliau mempersilahkan kiyai tersebut untuk menyampaikan khutbah jumat dan adzan pun dilakukan dua kali, karena tradisi di kalangan NU dilakukan demikian. Contoh lain, diceritakan bahwa Buya apabila mengimami shalat sunat tarawih beliau selalu bertanya dulu apakah jemaah hendak shalat 11 rakaat atau 23 raka'at. Maka Buya mengikuti keinginan jemaahnya. Hobat Habbatussauda, "Kisah Sederhana Antara Buya Hamka dan KH.Abdullah Syafi'ie”, 19 September 2011. madzhab Salaf. Artinya mengikuti Nabi dan para sahabat dan para ulama yang mengikuti jejak mereka.

Tafsir yang paling menarik hati Hamka adalah tafsir al-Manar yang ditulis oleh Sayyid Rashid Ridla. ${ }^{39}$ Tafsir ini mempunyai karakter khas yaitu dalam penafsiranya selain menggunakan pendekatan klasik juga mengunakan pendekatan perkembangan politik dan kemasyarakatan. Selanjutnya adalah Tafsir al-Maraghi, Tafsir al-Qasimi, dan Tafsir fi Dilal alQur'an. $^{40}$

https://www.facebook.com/notes/hobat-

habbatussauda/kisah-sederhana-antara-buyahamka-dan-khabdullah-

syafiie/263017877065461?ref=nf $\quad$ (accessed May 09, 2013).

${ }^{39}$ Untuk mengetahui ikhtisar tentang Tafsir alManar dan pengarangnya, silahkan lihat $\mathrm{M}$. Quraish Shihab, Rasionalitas al-Qur'an (Jakarta: Lentera Hati, 2006). Pendekatan yang dipakai adalah oleh Hamka dalam tafsirnya sama dengan apa yang dipakai Rashid Ridha yaitu pendekatan yang sesuai dengan kondisi kontemporer yang telah dimodifikasi dan dihubungkan dengan berbagai lapisan masyarakat modern. Dalam ilmu tafsir pendekatan ini disebut Adabi Ijtima'i. Lihat Mustaffa Abdullah, Faisal Ahmad Shah, Ishak Suliaman, Mohd. Yakub Zulkifli Mohd Yusoff, Monika Munirah Abd Razzak, Fauzi Deraman, Khadher Ahmad, Mohd Murshidi Mohd Noor, Jilani Touhami Meftah, Sedek Ariffin, Ahmad K. Kasar, Selamat Amir, Faisal Ahmad Faisal Abdul Hamid and Mohd Roslan Mohd Nor, "Sayyid Muhammad Rasyid Rida's Influence on Tafsir Studies in Malaysia", Middle-East Journal of Scientific Research 12, no.6 (2012) : h. 6.

40 DR. Salah Abdul Fattah menulis disertasi tentang tafsir ini. Beliau mendapatkan nilai Mumtaz (Cumlaude) dalam pemikiran tafsir al-Qur'an. Menurut Salah, tafsir ini banyak yang salah memahaminya. Bahkan ada yang menilai bahwa kitab ini bukan tafsir. Padahal menurut penelitian beliau ini, ad-Dilal merupakan madrasah modern dalam tafsir. Lihat Shalah Abdul Fattah al-Khalidi, Tafsir Metodologi Pergerakan (Jakarta: Yayasan Bunga Karang, 1986), h. 4. Buku tersebut adalah terjemahan dari buku al-Manhaj al- 
Menurut pandangannya, tafsir ini merupakan tafsir yang paling representatif dengan konteks kekinian (Hamka: munasabah). Dalam segi riwayat, tafsir ini di bawah al-Manar. Namun dari segi dirayah, sangat cocok dengan nalar pembaca pasca perang dunia kedua. Yang kita namai dengan zaman atom. Tafsir ini sangat mempengaruhi Hamka dalam tafsirnya.

Secara keseluruhan pada Juz I, beliau menyebutkan bahwa referensinya terdiri dari 45 nama buku yang disebutkan secara ekplisit. Beliau juga mengutip berpuluh-puluh kitab karangan sarjana-sarjana modern dan karangan-karangan Orientalis Barat yang bagi para mufassir Indonesia lain mungkin hal ini adalah hal yang tabu. Yang terakhir ini juga telah menjadi kharakteristik khusus Tafsir al-Azhar.

\section{Prioritas Corak (Manhaj) Tafsir Hamka}

Peter Riddel (2001), dalam catatan kaki di dalam bukunya Islam and The Malay Indonesian World, mengutip bahwa Hamka dalam penafsirannya cenderung kepada corak yang diformulasikan oleh Ibnu Taymiyyah (w. 1328 M/728 H). Ibnu Taymiyyah mengembangkan penafsiran dengan pendekatan tafsir yang memprioritaskan wahyu daripada akal. Secara berurutan, menurut Ibnu Taymiyyah, sumber penafsiran itu adalah al-Qur'an, alHadith, perkataan sahabat dan perkataan tabi'in ${ }^{41}$. Metode ini dalam kajian tafsir dikategorikan ke dalam kelompok tekstual (tafsir bil ma'tsur).

Sekarang yang menjadi pemasalahanya adalah apakah Hamka

Haraki fi Dilal al-Qur'an yang dilakukan oleh Asmui Solihan Zamakhsyari.

41 Peter Riddel, Islam and The Malay Indonesian World (Singapore : Horizon Books, 2001), h. 23. mengaktualisasikan kecondongannya kepada pendapat Ibnu Taymiyyah, yaitu yang berkiblat kepada Tafsir bil Ma'tsur di dalam tafsirnya. Hal ini bisa ditentukan apabila kita melihat dan menelitinya dalam sistematika penulisan yang akan menjadi pembahasan selanjutnya. Akan tetapi secara umum, berdasarkan penelitian sebelumnya, dapat disimpulkan bahwa Hamka mencoba menghubungkan antara sejarah Islam modern dengan studi al-Qur'an dan berusaha melangkah keluar dari penafsiran-penafsiran tradisional. Titik tekannya adalah menguak ajaran al-Qur'an dan menyesuaikannya dengan konteksnya dalam ranah keislaman ${ }^{42}$.

\section{Sistimatika Penulisan (thariqah)}

Dalam penafsirannya, Hamka membuka tafsir ini dengan pembahasan tentang definisi al-Qur'an, isi mukjizat al-Qur'an, al-Qur'an lafadz dan makna, menafsirkan al-Qur'an, haluan tafsir, alasan pemberian nama Tafsir al-Azhar, dan menguraikan hikmah ilahi setelah proses penafsirannya.

Hamka mengomentari tentang 'Ijaz al-Qur'an. Menurut beliau Ijaz Nabi yang bersifat hissi (bisa diliha oleh mata) seiring zaman sudah menurun keampuhannya dalam menunjukkan ego manusia. Yang tersisa adalah mukjizat beliau al-Qur'an yang berlaku sepanjang zaman dan untuk varian bangsa untuk dilihat secara akal. Kekuatan al-Qur'an mampu melemahkan semua ego manusia. Jelas sekali di dalam komentarnya ini, bahwa beliau ini sangat kontekstual dalam memposisikan suatu permasalahan. Walaupun masalah tersebut mempunyai

\footnotetext{
${ }^{42}$ Saiful Amin Ghafur, Profil Para Mufassir alQur'an, h. 212.
} 
nilai-nilai lebih yang lain yang membuat takjub. ${ }^{43}$

Metode penulisan tafsir yang dipakai adalah metode penafsiran ayat secara berurutan dimulai dari surat alFatihah sampai kepada surat al-Nas. Metode ini disebut metode Tahlilii. Secara bahasa metode ini bersifat analisis. Semua objek penafsiran dikupas secara terperinci dan teratur (reguler).

Adapun metode penulisan yang dilakukan pada saat menafsirkan adalah dengan tahapan-tahapan sebagai berikut:

1. Menuliskan ayat dan terjemahnya

2. Menjelaskan makna nama surat dan identitas lainya seperti tempat dan waktu turunnya

3. Menyebutkan Sabab al-Nuzul dari ayat bersangkutan kalau ada

4. Menyebutkan tafsir bil al-Qur'an, hadits dan qaul sahabat dan tabi'in

5. Menyebutkan sirah Nabi, sahabat dan para shalihin kalau ada

6. Mengemukakan perbedaan pandangan para mufassir

7. Mekorelasikan kandungan ayat dengan konteks pengarang

8. Membuka pengalaman kehidupan pribadi, orang lain yang ada korelasinya. $^{44}$

9. Menyebutkan syair-syair kuno

10. Mengakhirinya dengan kesimpulan serta ajakan untuk mentadabburinya. ${ }^{45}$

43 Hamka, Tafsir al-Azhar, (Jakarta: Citra Serumput Padi, 1982), h. 12.

${ }^{44}$ Sebagai contoh beliau menceritakan seekor kucing kesayangann ayahnya yang ada di rumahnya. Ayahnya biasa memberi makan sendiri, dan beliau sering menanyakan kucing itu setiap hendak pergi dan datang. Ketika meninggal ayahnya, ajaibnya sehari sebelum meninggal kucingnya ditemukan meninggal di sumur terlebih dahulu, besoknya ayahnya pun meninggal. Lihat Hamka, Tafsir al-Azhar, h. 98.

45 Saiful Amin Ghafur mempunyai rangkaian sendiri dalam langkah taktis penafsiran
Sistematika penulisan tersebut merupakan kesimpulan penulis yang bersipat sementara. Penulis tidak sempat membaca tafsir ini seluruhnya. Sehingga membuka kemungkinan lain untuk mengkritisi dan mengubahnya atau mungkin menambahkannya.

\section{Karakter Khas Tafsir al-Azhar}

1. Terkadang menyebutkan sejarah dan Hikmah kuno (selain para sahabat) Sebagai contoh ketika beliau menafsirkan al-Baqarah : 105-107. Beliau mengutip nasihat Kong $\mathrm{Hu}$ $\mathrm{Cu}$," Sebelum aku mengurus hal negara, lebih dulu aku hendak menyelesaikan pengertian dari setiap kata yang dipakai". Juga pujangga Prancis, Voltaire berkata “ Sebelum dua orang bertukar pikiran, hendaklah mereka terlebih dahulu bersepakat tentang arti kalimat yang hendak mereka bicarakan". 46

2. Menyebutkan pengalamanpengalaman orang yang hidup di sekeliling Hamka, orang yang sengaja bertanya, berdiskusi dan minta nasihat kepadanya. Dengan catatan bahwa data tersebut lebih memberikan penjelasan yang lengkap terkait ayat yang ditafsirkann. ${ }^{47}$

Hamka, yaitu menulis teks al-Qur'an dan terjemahnya, memberikan catatan penjelasan, menyajikan bagian-bagian pendek (1-5 ayat) lengkap dengan terjemahnya, menjelskannya secara panjang lebar, bisa sampai 15 halaman. Lihat Saiful Amin Ghafur, Profil Mufassir alQur'an, (Yogyakarta: Pustaka Insan Madani, 2008), h. 212.

${ }^{46}$ Hamka, Tafsir al-Azhar, h. 335.

47 Lihat Rosnani Hashim (ed), "Hamka: Intellectual and Social Transformation of the Malay World" In Conversation Islamic Intellectual Traditionin the Malay Archipelago, (Kuala Lumpur: Pustaka Perdana, 2010), h. 231. 
3. Akomodatif terhadap pendekatan semua ilmu dan sains yang yang ada korelasinya dengan penafsiran termasuk filsafat. Menurut Hamka, penemuan-penemuan Sains yang baru telah menolong kita untuk memahami kebenaran ayat alQur'an dan melihat keagunganNya. Beliau berpendapat bahwa 'ilm, aql dan rasionlitas tidak eksis dengan sendirinya, kecuali diperuntukkan manusia untuk mengenal Tuhannya. Seperti dalam menafsirkan surah al-Isra : $36 .^{48}$

4. Gaya bahasanya adalah gaya bahasa lisan. Dalam tata bahasanya terkadang bertentangan dengan Ejaan Yang Disempurnakan (EYD)

5. Dalam setiap penafsiran terhadap satu tema. Hamka selalu mengakhirinya dengan pesan akhlak yang tersimpan dalam ayat.

6. Dalam setiap pemaparan dalam setiap tafsir melalui pendekatan sosial masyarakat, yang ditampilkan adalah adat melayu. Latar belakang suku beliau sebagai seorang tokoh melayu yang fanatik. Kecenderungannya untuk menjadikan masyarakat melayu yang Islami sangat kental. Apalagi memang tafsir ini berbahasa Indonesia yang diutamakan tujuan penulisannya untuk konsumsi pembaca dari masyarakat melayu.

Sebagai contoh adalah ketika beliau menafsirkan kata ilah dan Allah menurut Hamka dalam Bahasa Melayu kata ilah ialah dewa dan tuhan. Seperti tersurat dalam batu Trengganu (disimpan di Museum Kuala Lumpur) yang ditulis kirakira tahun 1303 M. Kata Allah Swt

48 Lihat Rosnani Hashim (ed), "Hamka: Intellectual and Social Transformation of the Malay World" In Conversation Islamic Intellectual Traditionin the Malay Archipelago, h. 233. diartikan dengan Dewata Mulia Raya. Akhirnya seiring dengan masa, kata Tuhan dipahami oleh orang Islam Indonesia dan Melayu ( $\mathrm{T}$ besar) diartikan dengan Allah. Sedangkan term dewa tidak dipakai lagi. Beliau membandingkannya dengan term-term untuk Tuhan dari bahasa lainnya, yaitu Gusti (Jawa), Pangeran (Sunda), Poang (Bugis dan Makasar). ${ }^{49}$

7. Susunan kata berirama puitis

8. Salah satu sumbernya juga berasal dari buku-buku karangan Sarjana modern dan Orientalis Barat. Beliau tidak malu untuk mengutipnya dari kitab-kitab tafsir Indonesia yang hidup sezaman dengannya. Di antara kitab tafsir Indoneisia itu adalah Tafsir al-Furqan (A. Hasan), Tafsir al-Qur'an al-Karim (Mahmud Yunus), Tafsir al-Nur ( M. Hasbi al-Shiddiqi), Tafsir alQur'an al-Hakim (Qasim Bakri dkk), Tafsir Depag dan lain-lain. ${ }^{50}$

9. Keunikan tafsir ini adalah kemampuannya berelasi terhadap isu-isu kontemporer, kepada budaya masyarakat terutama budaya Melayu-Minangkabau, termasuk pengalamn hidupnya. Sebagai contoh adalah ketika beliau menafsirkan surah al-Baqarah: 195. Yang berhubungan dengan fi sabilillah. Dia menceritakan cerita TNI yang diketuai oleh Jendral Sudirman dan Front Hizbullah ketika berperang Jihad fi Sabilillah. Di dalam menafsirkan ayat 209 pada beberapa juz, Allah tidak menonton untuk mengikuti langkah-langkah syaitan, Hamka menceritakan bagaimana negara-negara Muslim atau individual menolak perintah Allah dan mengajak supaya

\footnotetext{
49 Hamka, Tafsir al-Azhar, (Jakarta: Pustaka Panji Mas , 2005), h. 90.

${ }^{50}$ Hamka, Tafsir al-Azhar, h. 421.
} 
mengikuti keputusan Kamal Ataturk, pemimpin sekuler Turki. Dia juga menceritakan bagaimana masyarakat Buton, Sulawesi mematuhi perintah Allah dan menerapkan hukum hudud untuk pencuri dan zina. Meskipun bekas daerah jajahan Belanda. Beliau bahkan menceritakan pengalaman pribadinya ketika berdiskusi dengan anaknya, menjelaskan beberapa ayat seperti surah al-Baqarah: 219 yang berhubungan dengan tertutupnya pertolongan Allah. Berhubungan dengan keputusan dipenjara. Beliau juga menceritakan pengalaman gurunya berpoligami ketika menafsirkan Surah An-Nisa. ${ }^{51}$

Penulisan tafsir beliau selesaikan ketika beliau sedang berada di penjara. Sel penjara beliau jadikan tempat untuk bermujahadah kepada Allah. Beliau menggoreskan pena untuk tafsir ini di penjara Sukabumi, atau di Bungalau "Herlina dan Harjuna" di Puncak. Atau di Mess Brimob di Mega Bandung, atau sambil berbuat sambil di tahan di rumah sakit Persahabatan di Rawa Mangun. Wajah-wajah jema'ah beliaulah yang terbayang ketika Hamka mulai mengoreskan pena untuk menulis tafsir. $^{52}$

Hamka menuliskan tafsir ini biasanya tiap-tiap pagi waktu subuh. Penulisannya dimulai sejak akhir tahun 1958 sampai Januari 1964, itu pun katanya belum tamat. Agar catatan aslinya itu redaksinya dapat dijaga keotentikannya maka ia menuliskannya di majalah Gema Islam sejak Januari

\footnotetext{
51 Lihat Rosnani Hashim (ed), "Hamka: Intellectual and Social Transformation of the Malay World" in Conversation Islamic Intellectual Traditionin the Malay Archipelago, h. 231.

52 Hamka, Tafsir al-Azhar, (Jakarta: Citra Serumput Padi, 1982), h. 42.
}

1962 sampai Januari 1964, namun yang bisa dimuat baru satu setengah juz saja, yaitu juz 18-19.

\section{Corak Kalam Tafsir al-Azhar Berdasarkan Penelitian Yunan Yusuf}

Permasalahan kalam yang ada semenjak terjadinya arbitrase yang terjadi pada masa Ali, mempunyai impllikasi yang sangat besar terhadap variasi madzhab-madzhab kalam. Objek Ilmu Kalam - Tuhan dan manusia- yang sekaligus juga merupakan subjek terbesar dalam kehidupan ini, dengan catatan tentunya apa yang dinisbahkan kepada Tuhan sangat berbeda dengan apa yang dinisbatkan kepada manusia. Diskursus kalam tidak akan luntur sejalan dengan habisnya umur, tetapi malah akan semakin menjamur. Terlebih lagi pada zaman modern ini, perhatiam umat Islam terhadap pembahasan ini semakin besar. Hal ini disebabkan umat sudah dapat mengakses dengan mudah terhadap alQur'an, Hadits, ajaran-ajaran, dan ilmu-ilmu agama melalui media yang terus semakin berkembang.

Berikut ini penulis akan membahas sedikit ulasan Hamka tentang posisi akal dan konsep free will yang menjadi perbincangan pokok dalam ilmu kalam. Pembahasan akal sebelum menuju kepada aspek Tasawuf karena akal menjadi antitesa dari instuisi (instuitif). Namum demikian, pemahaman tersebut tidak sepenuhnya benar. Karena jalan melalui Tasawuf yang baik tentu saja berawal dari peranan akal dalam awal hidayahnya.

Tafsir al-Azhar tampil sebagai salah satu agen Tuhan yang mendapatkan amanah untuk menyampaikan risalah ilahi, terutama yang berkaitan dengan Tuhan dan 
makhluknya. ${ }^{53}$ Bagaimakah kedudukan akal dalam Tafsir al-Azhar?

Hamka berkata dalam tafsirnya, "Yang terpenting daripada kelebihan manusia dengan akalnya adalah kesanggupannya membedakan dan menyisihkan di antara yang buruk dan yang baik. Manusia melihat kepada alam sekeliling dengan panca indranya. Maka menggetarlah apa yang kelihatan dan kedengaran itu ke dalam jiwa. Maka tergambarlah bekasnya itu di dalam jiwa tadi dan menjadi kenangan. Dengan melihat dan mendengar, tergambar dan mengembang itulah manusia membentuk persediaannnya menempuh hidup. Dengan itu pulalah ia dapat mengenal mana yang baik mana yang buruk, mana yang jelek mana yang indah.

Menurut Yunan Yusuf, posisi akal yang digambarkan Hamka di atas belum menggambarkan daya yang besar. Perlu dilakukan penelusuran lebih lanjut tafsir Hamka terhadap ayat-ayat kalam secara langsung. Hamka mengatakan ketika menafsirkan ayat dalam surat Fussilat, bahwa dengan jalan berfkirlah (mempergunakan akal) isyarat-isyarat Allah dalam al-Qur'an dapat terbuka secara sempurna. Ayat-ayat yang tidak dipahami di masa lampau, akhirnya dapat terbuka setelah dipahami oleh akal beberapa puluh atau bahkan

\footnotetext{
53 Sufi klasik yang melakukan penafsiran melalui pendekatan filsafat ketuhanan adalah Ibnu 'Arabi. Sebagaimana yang ditulis dalam buku Nasir Hamid yang berjudul Falsafat alTa'wil. Beliau menjelaskan secara terperinci hubungan Tuhan, alam sebagai makrokosmos dan manusia sebagai mikrokosmos, ma'rifat, syari'at, hakikat dan relasi antara bahasa dan alam raya dan diakhir pembahasan beliau menetapkan konsep ta'wil. Nasr Hamid Abu Zayd, Falsafat al-Ta'wil: Dirasah fi Ta'wil al-Qur'an 'inda Muhyi al-Din bin 'Arabi, (Beyrut: al-Markaz al-Thaqafi al-'Arabi, 1996), h. 427.
}

ratusan tahun sesudahnya. ${ }^{54}$ Jadi, intinya otak manusia itu selalu berputar. Ini mungkin yang menjadi kesimpulan Hamka dalam menafsirkan surat Fusilat tersebut.

Sebagai konsekuensi dari anugrah Tuhan berupa akal yang merdeka. Hamka menegaskan sikap penentangannya terhadap taklid. Taklid menyebabkan kebekuan berfikir yang berimplikasi kepada kebekuan beragama dan pudarnya sinar agama. Sikapnya ini dapat digambarkan ketika beliau menafsirkan surat al-Isra': 36 . Menurut Hamka, kata wala taqfu mengandung arti jangan mengikuti jejak. Orang yang taklid biasanya tidak bisa mempergunakannya pertimbangannya sendiri. Terutama dalam beragama, orang yang taklid cenderung mencampurkan antara sunnah dan bid'ah karena dia sudah tidak bisa memfilter amalan-amalan tersebut. Itulah sebabnya kita wajib beragama dengan berilmu. 55

Bila diperbandingkan wewenang yang diberikan Hamka bagi akal dengan wewenang yang diberikan oleh aliranaliran kalam bagi akal, maka dapatlah ditarik persamaan antara pemikiran Hamka dengan pemikiran yang terdapat dalam aliran Maturidiyyah Bukhara sama-sama memberikan wewenang kepada akal untuk mengetahui bahwa Tuhan itu ada dan untuk mengetahui mana yang baik dan yang buruk. Sebagaimana yang disinggung terdahulu, bahwa dalam pandangan Maturidiyyah Bukhara, akal manusia tidak mampu untuk menentukan kewajiban manusia. Akal hanya dapat mengetahui sebab dari kewajiban manusia. Atau dengan kata lain, akal bagi Maturidiyyah adalah sebagai alat

\footnotetext{
${ }^{54}$ Yunan Yusuf, Corak pemikiran Kalam Tafsir al-Azhar, h. 125.

${ }^{55}$ Yunan Yusuf, Corak Pemikiran Kalam Tafsir al-Azhar, h. 128.
} 
bagi manusia untuk mengetahui kewajiban-kewajibannya. Jadi, corak pemikiran kalam Hamka dalam masalah kekuatan akal sama dengan Maturidiyyah Bukhara.

\section{Pandangan Hamka Terhadap Free Will dan Predestination (Qadariyyah dan Jabariyyah)}

Hal ini akan terasa lebih jelas apabila kita melihatnya dalam penafsiran beliau tehadap surat alSaffat: 95-96, yang dijadikan Ash'ariyah bahwa perbuatan manusia juga merupakan ciptaan Tuhan. "Padahal Allah-lah yang menciptakan kamu”, pangkal ayat 96. Menciptakan kamu sejak dari saringan tanah liat di permukaan bumi, ditumbuhkan menjadi sayur, buah-buahan, padi, kacangkacangan, gandum dan sebagainya. Lalu dimakan oleh ayah bundamu, lalu menjadi darah dan darah mengeluarkan saringannya yaitu mani. Itulah yang dijadikan rahim itu menjadi insan. "Dan apa yang kamu kerjakan”. Karena berhala-berhala yang kamu sembah itu adalah hasil pekerjaanmu sendiri dan yang kamu kerjakan itu hasil ciptaan Allah juga. Baik dia batu yang tergeletak di pinggir bukit atau di pohon kayu yang tumbuh lebat. Semua itu Allah yang menciptakan mengapa tidak ada saja yang langsung kamu sembah dan kamu puja. ${ }^{56}$

\section{Aspek Tasawuf Dalam Tafsir al-Azhar}

Pada pembahasan sebelumnya dikatakan bahwa Hamka memasukkann ajaran akhlak sebagai salah satu isi dari kemukjizatan al-Qur'an (i`jaz alQur'an). Dalam perkembangannya ke depan setelah turunnya al-Qur'an. Nilai-nilai etika (akhlak) yang terdapat

\footnotetext{
${ }^{56}$ Yunan Yusuf, Corak pemikiran Kalam Tafsir al-Azhar, h. 138.
}

di dalam al-Qur'an ini kemudian banyak diinternalisasikan ke dalam Ilmu Tasawuf. Objek ilmu ini terdiri dari tiga sasaran. Akhlaq terhadap Allah, manusia dan lingkungan.

Hamka dalam perjalanan hidupnya, dikatakan bahwa beliau juga secara otodidak fokus mempelajari ilmu tasawuf. Hasil dari keakrabannya dengan ilmu ini, beliau berhasil membuat buku dengan judul Tasawuf Modern. ${ }^{57}$ Dalam bidang ini Hamka disejajarkan dengan Hamzah Fansuri. ${ }^{58}$ Dengan cirinya yang khas, Hamka berhasil membawa ajaran Tasawuf kepada tempat yang seadil-adilnya. Malah beliau pernah berkunjung kepada seorang sufi Agung Abah Anom di Suryalaya, Tasik Malaya, Jawa Barat. Ketika itu beliau masih menjabat ketua MUI. Karya beliau yang lain dalam bidang Tasawuf adalah Tasawuf, Perkembangan dan Pemurniannya. Berdasarkan kedua karya beliau ini, maka sudah jelas bahwa kecenderungan

\footnotetext{
57 Dalam buku ini beliau berhasil mengajak muslim modern untuk menghargai esensiesensi Tasawuf yang bernilai positif dan bisa dipelajari oleh umat Islam secara umum serta tidak memerlukan latihan dalam waktu yang lama di bawah bimbingan seorang Guru. Lihat Martin Van Bruinessen and Julia Day Howell (ed), "Sufisme and Modern In the Islam" (London and New York: I.B. Tauris, 2007), h. 229.

${ }^{58}$ Hamzah al-Fansuri (w. $1607 \mathrm{H}$ ) seorang sufi terkemuka dan sheikh paham Wujudiyyah. Tepatnya pada masa Sultan Ala'uddin Ri'ayat Syah dan awal pemerintahan Sultan Iskandar Muda di Kerajaan Aceh tahun 1550-1605 H. Jejaknya agak sulit diikuti oleh ahli sejarah, tidak seperti rekannya Nuruddin al-Raniri. Namun telah ditemukan adanya dua karya beliau yang berupa sya'ir-sya'ir dan disyarahi oleh Syamsudin al-Sumatrani. Yaitu Sharh Ruba'i al-Sheikh Hamzah al-Fansuri dan Sharh Sya'ir Ikan Tongkol. Lihat Tim Penulis UIN Syarif Hidayatullah, Ensiklopedi Tasawuf (Bandung: Angkasa, 2008), jilid I, h. 441. Lihat juga Alwi Shihab, Islam Sufistik (Bandung: Mizan, 2001), h. 124.
} 
beliau ke dalam Tasawuf mewarnai kebanyakan pendekatan beliau dalam mengajarkan Islam. Namun demikian, beliau bukanlah juru bicara para Sufi Indonesia yang mendominasi sejak abad 16 sampai abad 19. Tidak bisa dipungkiri bahwa beliaulah yang menggagas dan sekaligus sebagai juru bicara untuk Tasawuf Modern (1939). Beliau menjauhi statement-statement anti sufi modern dengan mengkritik Tasawuf yang bertentangan dengan praktek Islam. Kontribusi beliau ini memasukan beliau ke dalam golongan cendikiawan moderat. Dan menghantarkannya untuk menjabat ketua Council of Islamic Schoolar of Indonesia (MUI). ${ }^{59}$

Sebuah contoh dari internet beliau adalah buku Pelajaran Agama Islam (Studing Islam). Dalam satu tema, beliau mendiskusikan judul Malaikat, Jin dan Spiritual. Komponen-komponen kunci dari referensinya adalah menghubungkan diskusinya ke dalam tataran konteks modern. Bertahan dengan apa yang ia lihat sebagai modern dan serangan apa yang ia anggap sebagai modern. Janganlah para pembaca keasyikan untuk membuktikan eksistensi malaikat. Bidang malaikat adalah pengalaman murni, bukan dengan intelektual semata. ${ }^{60}$ Memahami malaikat tidak dengan kata tanya apa dan di mana. Mereka tidak identik dengan bentuk (form), tidak butuh ruang (space) dan waktu (time). Latihan spiritual dan pengalaman yang kontiunitas dalam kurun waktu lama akan mengantarkan kita pada eksistensi malaikat.

Beliau mengajak membahas Qs.41:30 yang sub-temanya tentang fungsi malaikat. Beliau menambahkan

\footnotetext{
59 Peter Riddel, Islam and The Malay Indonesian World, h. 218.

60 Peter Riddel, Islam and The Malay Indonesian World, h. 218.
}

bahwa beriman kepada malaikat merupakan rukun iman yang enam. Namun apabila salah menafsirkan akan menyebabkan orang jatuh ke dalam praktik salah dan efeknya terhadap lingkungan. Tidak jauh seperti masalah menerangkan lilin sesaji kepada orang keramat, menghadirkan malaikat dan lain-lain. ${ }^{61}$

Dalam kesempatan ini, penulis berusaha menelusuri ayat-ayat yang sudah umum dijadikan dasar-dasar pijakan orang-orang sufi dalam prakteknya. Ayat-ayat tersebut adalah dalil yang dijaadikan para sufi untuk melegitimasi ajarannya-ajarannya. ${ }^{62}$ Doktrin-doktrin tasawuf yang akan dibahaas yang merupakan doktrindoktrin yang terdapat pada kedua kitab Kasyful Mahjub dan al-Risalah alQuraishiyyah yang dasar hukumnya terdapat dalam ayat-ayat al-Qur'an. Penelitian ini akan meneliti bagaimanakah Hamka menguraikan ayat-ayat tersebut dalam persfektif tasawuf.

\section{Tafsir Al-Hadid : 1-3}

61 Peter Riddel, Islam and The Malay Indonesian World, h. 220.

${ }^{62}$ Didalam kitab Tasawuf yang paling otoritatif dalam membahas para Sufi dan ajaranajarannya adalah al-Risalah al-Qushayriyyah. Kitab ini membahas biografi para sufi sebanyak 83 orang dan ajarannya sebanyak 28 pembahasan serta stasion-stasion para sufi (maqamat) 76, termasuk di dalamnya adalah etika antara Sheikh dan Murid. Lihat Abi alQasim abd al-Karim bin Hawazin al-Qusayry, al-Risalat al-Qushayriyyah (Damsyik: Maktabah al-Imam al-A'dzam Abi hanifah dan Damsyik: Maktabah al-Ilm al-Hadits, 2000), h. 608. Kitab lain yang otoritatif adalah Kashf al-Mahjub. Dalam kitab ini pengarang lebih mendefinisikan pembahasan Tasawuf di bawa menuju persfektifnya. Aku pun pembahasannya sedikit dan juga dibahas didalmnaya tentang pengarang kitab sekaligus karyanya ditinjaubdari berbagainaspek. Lihat al-Hujwiri, Kashfuln Mahjub (Mesir: al-Kitab al-Tisun, 1974), h. 394. 
Pada pembahasan yang pertama tentang kajian corak Tasawuf dalam Tafsir ini adalah doktrin-doktrin Tasawuf yang terdapat dalam Surat alHadid. Dalam surat ini ada 3 doktrin yang dapaat diuraikan, yaitu tasbih (Qs. 57: 1-3), khusyu' (Qs. 57: 15) dan rahbaniyyah (Qs. 57: 26) yang penulis relevansikan dengan doktrin 'uzlah.

Pembahasan Hamka dalam menafsirkan kata tasbih dalam al-Hadid ayat 1 adalah bahwa mengucapkan tasbih ialah menyatakan rasa syukur, mengakui kesucian dan kemuliaan ilahi di dalam semua gerak ciptaanya yang ada di dalam alam. Jika sekiranya manusia mengucapkan tasbih itu dan perlakuan dengan lidah, subhanallah, maka seluruh alam ini pun mengucapkan tasbih, masing-masing menurut cara dan perlakuan yang layak baginya. Hamka menceritakan pengalamnnya pada tahun 1948 , beliau pernah melintasi hewan belantara. Ketika mulai gelap, maka hutan serasa kuburan, sunyi senyap. Saat itulah, menurutnya, alam terasa bertasbih kepada Tuhannya. Dan beliau merasakan penjagaan Tuhan terhadap alamnya. Hamka dalam melakukan pendekatan terhadap alam ini dengan menggunakan perasaan (dzauq/instuisi) yang alami. Alam juga mempunyai posisi yang sama disisi Allah. Manusia bisa berkomunikasi dengan alam melalui perasaan yang halus. Dengan jelas dalam ayat ini, Hamka menafsirkan bahwa sudah seharusnyalah manusia berkompetensi dengan alam untuk bertasbih kepada Tuhannya. Manusia yang mempunyai akal, harusnya lebih sadar akan tugas manusia dalam hubungan dengan Tuhannya.

Selanjutnya dalam menafsirkan sifat Allah Yang Menghidupkan (alMuhyi) dan Yang Mematikan (al-
Mumit). Beliau menyatakan bahwa orang yang mempunyai hati bersih. Ia akan melihat kekuasaan Allah untuk menghidupkan sekaligus mematikan itu dengan basirah. Ia merasa siklus hidup mati ini senantiasa berputar sepanjang masa. Berbagai corak hidup dan corak mati dalam alam ini, yang selalu dapat kita perhatikan, yang tidak berhenti keajaibannya baik di darat maupun di laut. Lumut yang tumbuh dalam lautan, dikipas-kipaskan oleh air laut yang selalu berombak, beralun ternyata hidup. Hidup di tempatnya bukan mencari makan, melainkan makan mencari dia. Semua ini menunjukan kemahakuasaan Allah.

Dalam menafsirkan 2 kata yang merupakan saling berkebalikan makna, Hamka berusaha untuk menghubungkan antara kekuatan bashirah untuk menangkap kekuatan Tuhan dalam perbuatannya mematikan dan menghidupkan makhluk-Nya. Memang secara teori Tasawuf kata ini tidak ada korelasinya dengan doktrin Tasawuf. Akan tetapi apabila diteliti lebih mendalam dan secara praktikal, pembacan seorang Sufi dalam tragedi kematian dan kehidupan merupakan salah satu pintu menuju Tuhan. Sufi yang melakukan hal tersebut, akan merasa bahwa dirinya sangatlah lemah (dha'if), dan sangat tergantung kepada Allah kelangsungan hidupnya. Dia merasa mungkin Tuhan akan mematikannya.

Selanjutnya dalam menafsirkan kata al-dahir. Ini merupakan salah satu sifat Allah. Tuhan itu jelas dan terang, tidak diragukan lagi, karena Tuhan itu dilihat oleh bashirah (hati) dan melihat bukti dari perbuatannya. Sampai para ahli mengatakan bahwa tidak mungkin alam ini terjadi karena alam belaka. Telah berjuta-juta tahun perjalanan bumi mengelilingi matahari dengan sangat teratur. Demikian pula bulan 
mengelilingi bumi dengan sangat teratur. Ini adalah tanda dzahirnya Allah. Dan Dia juga al-Batin, tidak dapat dilihat, namun dapat dilihat di hati. Itu lah sebabnya mengapa manusia diberi hati. Inilah yang dikatakan ahli Tasawuf.

"Aku ini adalah perbendaharaan yang tersembunyi, lalu Aku ciptakan hambaku, dengan karunia-Ku lah mereka dapat mengenal Aku."

Dalam penafsirannya tersebut, Hamka mengajak pembaca untuk mengenal (ma'rifat) kepada Tuhannya. Maka setelah tahap pengenalan ini, mereka akan merasakan dengan jelas di mana posisi Tuhan dan di mana posisi dia yang dha'if. ${ }^{63}$ Selanjutnya doktrin Tasawuf yang akan dibahas pada tafsir al-Azhar masih pada surat yang sama ayat 15 , yaitu konsep uzlah.

Manusia dianugerahi akal untuk dijadikan alat dalam mengenali alam sekitar. Pengenalan yang dalam atau akrab timbul dari kegiatan perhatian yang lebih terhadap objek dibandingkan dengan objek lainnya. Dalam kondisi demikian maka dua pihak yang saling mengenal secara lebih jauh berarti kedua-duanya telah saling setia, tunduk, patuh terhadap keputusan. Informasi yang keluar dari kedua belah pihak.

Pengenalan terhadap Allah juga demikian, tidak akan mengenal secara mendalam terhadap Allah apabila usaha untuk mengenalnya sangat minim. Totalitas di dalam hal ini sangat diperlukan. Fokus terhadap Allah dan hal yang menghantarkan kepada-Nya harus benar-benar menjadi prioritas utama. Inilah tingkatan awal dari seorang yang dianugrahi Allah kesempatan untuk menjadi wali-Nya, yaitu khusyu'. Khusyu' merupakan

63 Hamka, Tafsir al-Azhar, (Jakarta: Citra Serumput, 1982), h. 269-272. pijakan awal, seorang salik seiring dengan mengawali perjalanannya menempuh jalan Sufi. Khusyu' menjadi pendorong utama bagi Allah untuk memberikan nur kepada hati HambaNya. ${ }^{64}$ Ketika ia mulai memberikan kecondongannya kepada Allah, maka Allah pun akan menyamputnya. Itulah bekas dari Khusyu'.

Khusyu kepada Allah dalam pandangan Hamka dalam Tafsir nya sebagai salah satu tanda seorang mukmin. Beliau mengkorelasikannya dengan Surat al-Anfal ayat 8 , bahwa salah satu tanda bagaimana pengaruh adanya iman itu kepada jiwa dan sikap kita. Dikatakan bahwa orang yang beriman itu bila disebut orang saja nama Allah, menjadi tersentuh hatinya dan apabila dibacakan orang kepadanya ayat-ayat Allah, imannya pun bertambah, dan dia pun bertambah bertawakkal kepada Allah. Khusyuk adalah hati yang rendah dan tunduk kepada Tuhan, yang insyaf akan kerendahan dan kelemahan diri berhadapan dengan kuasa ilahi. Apabila sifat khusyu sudah tertanam dalam jiwa, maka bersamaan dengan itu timbul juga tekad yang kuat hendak melaksanakan apa yang diperintahkan-Nya.

Menurut Abdullah bin Mubarak yang bersumber dari Shalih al-Muri, dari Qatadah dan dari Ibnu Abbas. Pertanyaan ini datang setelah 13 tahun masa sejak pertama turun. Bahkan menurutya satu riwayat dari Abdullah bin Mas'ud setelah 4 tahun kami menerima Islam, ayat ini baru turun. Ilmu bisa saja bertambah, ayat-ayat alQur'an bisa turun terus menerus. Akan tetapi hal yang lekas hidangnya dari sebagian muslimin adalah kekhusyuan kepada Tuhan.

$\begin{array}{ccr}\text { Rasul } & \text { bersabda } & \text { bahwa } \\ \text { sesungguhnya } & \text { yang } & \text { mula-mula }\end{array}$

${ }^{64}$ Qs. al-Saf (61) : 5. 
diangkatkan Allah dari hati manusia ialah kekhusyu'an itu. Allah melarang umat Islam, berlaku seperti Yahudi dan Nashrani, mereka membaca kitab suci nya setiap hari, bahkan sampai dihapalnya, namun tidak ada pengaruh dalam hatinya, sebab hati itu ielah kasar. Kitab sudah lama diterima, namun dia tidak berbekas lagi di hati. Dan banyak di antara mereka yang fasik.

Menurut Hamka, sikap kasar cerminan dari bahwa hatinya telah kasar, seharusnya mereka memahami terhadap perubahan sikap tersebut. AlQurtubi menjelaskan bahwa pemahaman mereka terhadap al-Kitab membuat mereka egoisme dan semua keputusan mereka tidak boleh dibantah.

Hamka mengkaitkan ayat ini dengan kedua sufi ternama, Adullah bin Mubarak dan Fudayl bin 'Iyad. Keduanya tersentak sadar ketika mendengar ayat ini. Ayat yang menjadikan mereka menjadi seorang zahid. Abdullah bin Mubarak menceritakan bahwa beliau disadarkan oleh seekor burung yang bernyayi. Namun nyanyiannya adalah bacaan Surat al-Hadid: 16.

Pada hal ini, Hamka terlihat tidak konsisten dengan pandangannya bahwa wali telah berubah yang dibahsa Hamka ketika menafsirkan surat Yunus. Wali bukanlah seorang yang sakti mandraguna. Penuh dengan hikmat dan karomah. Hamka menolak persepsi masyarakat umum tersebut. Namun, beliau sendiri malah menjadikannya sebagai materi penafsirannya. Hamka juga menyempurnakan tafsirnya ini dengan cerita yang menjadi sebab Fudayl bin 'Iyad yang menjadi seorang sufi. Fudayl jatuh cinta dengan seorang wanita cantik, namun ketika mendengar ayat tersebut Fudayl meninggalkan hidup demikian. Dan meneruskan perjalanan ke Makkah dan menetap di
Baitul Haram. Fudayl hidup sebagai seorang sufi besar sampai masa Khalifah Harun al-Rashid. ${ }^{65}$

Penafsiran Hamka terhadap term khusyu' tidak jauh dari makna redaksi itu sendiri. Hamka sangat kaya dengan materri tasawuf, namun hal itu tidak dipakainya untuk menafsirkan ayat-ayat Tasawuf dengan ajaran-ajaran Tasawuf yang sudah definitif. Beliau seolah-olah ingin membiarkan al-Qur'an bicara sendiri tentang Tasawuf.

\section{Uzlah}

Selanjutnya doktrin Tasawawuf yang terdapat dalam surat al-Hadid ayat 26 adalah uzlah. Dalam ayat ini memakai kata rahbaniyyah. Penulis merelevansikannya karaena adanya kesamaat tanda yang ada pada kata tersebut. Adapun secara etimologi keduanya sama-sama menghindar dari kerumunan hiruk-pikuk manusia, keduanya sama-sama berasal dan dinisbahkan kepada pendeta Nashrani.

Apakah konsep 'uzlah Hamka sama dengan uzlah dalam terminilogi Ilmu Tasawuf. Maka perlu adanya penelusuran terhapap ayat-ayat yang semakna degan kata uzlah. Dalam hal ini, penulis akan mentafsirkan surat alHadid: 27. Dalam ayat ini terdapat redaksi rahbaniyyah yang artinya kependetaaan. Hamka, menafsirkan bahwa kependetaan itu tidak diperintahkan oleh Allah. Namun hal itu keingian mereka sendiri untuk lebih prihatin menyembah Allah. Menurut sejarah dari sinilah berawal, adanya Gereja Vatikan, Paus beserta para pendeta berusaha untuk memelihara untuk tidak menikah, namun mereka tidak kuat menahannya. Mereka banyak melakukan penyimnpangan seksual yang terjadi di Gereja, sebagaimana

\footnotetext{
${ }^{65}$ Hamka, Tafsir al-Azhar, juz XXVII, h. 292.
} 
yang diklaim oleh Protestan, sebagai bentuk perlawanan terhadap mereka.

Hidup Coelibat atau kehidupan tidak beristri atau tidak bersuami adalah timbul dari perasaan mendalam terhadap beragama, meskipun agama sendiri tidak menyuruhnya. Hal tersebut nyaris juga terjadi pada masa Rasulullah, dimana sebagian sahabat ada yang hendak hidup membujang, tidak menikah, malam shalat siangnya dipakai untuk berjihad. Rasulullah menjawab bahwa Islam itu tidak mengenal konsep rahbaniyyah.

Islam lebih menghargai hal yang bersifat dinamis daripada statis. Kehidupan yang berjalan, berangkat pagi pulang malam untuk bekerja membanting tulang selama tidak melalaikan kewajiban beragama maka hal ini lebih Allah senangi dari pada hidup hanya untuk Ibadah ritual saja. ${ }^{66}$ Maksud Hamka, mungkin hidup yang benar-benar mendeskritkan kehidupan dunia. Hak-hak orang sekitarnya menjadi terlalaikan.

\section{Konsep Wali Telah Berubah}

Hamka menyarankan agar manusia melatih diri menjadi Wali dari Allah. Artinya menjadi orang yang qarib, yaitu orang yang dekat dengan Allah. Pelatihan ini akan berbuah kegembiraan sebagaimana disebutkan ayat sebagai karakter mereka. Dalam menafsirkan kata Wali secara utuh, Hamka mengkorelasikannya dengan pembahasan pada surat al-Baqarah: 257, al-Anfal: 72 dan al-Tawbah: 71 . Komplemen ayat-ayat tersebut merekonstruksi sosok wali yang utuh.

Wali adalah kelompok yang menjadikan Allah sebagai pemimpinnya, berhijrah, berjihad melalui jiwa dan harta benda. Menurut

\footnotetext{
${ }^{66}$ Hamka, Tafsir al-Azhar, juz XXVII, h. 308.
}

Hamka, secara bahasa, semua orang bisa menjadi wali. Allah adalah wali, orang mukmin juga wali, pengasuh anak yatim juga wali, pengasuh orang idiot juga wali. Menurut Hamka, semua orang harus berusaha menjadi wali dengan bertaqarrub. Karena Allah sendiri sudah terlebih dahulu mendekati hamba. Wali bertingkat-tingkat dan yang memberi pengakuan kewalian mereka adalah Allah sendiri. Sekaligus juga mereka mendapatkan jaminan perlindungan dari-Nya. Khawf menurut Hamka adalah duka cita yang timbul karena mengenangkan maksud yang tidak dicapai dan atau kehilangan yang dicintai. Seorang wali karena sudah bulat hatinya kepada Allah maka ia tidak akan terpengaruh olehnya.

Pada umumnya, dalam tafsirnya Hamka mengkonsepsi wali sebagaimana konsep umum dalam studi Tasawuf. Namun ada tambahantambahan ulasan khas, beliau dalam penjelasannya. Ucapan khas beliau seperti dikatakan bahwa wali itu tidaklah tidak punya rasa sedih dan takut secara mutlak. Karena keduanya adalah naluri atau insting. Nabi Muhammad saja, menamai tahun wafat istri dan pamannya adalah am huzn (tahun kesedihan). Demikian juga berita wafat putranya, Ibrahim diakui sebagai penyebab kesedihannya. Seraya mengutip Ibnu Khaldun, Hamka mengartikan Kashshaf adalah dibukanya dinding yang membatas di antara dirinya yang hidup dalam alam syahadah dengan kehidupan alam rohaniah yang lebih tinggi. Karena kalau ruh telah terlatih sehingga mencapai kekuatannya, maka lemahlah pengaruh tanggapan yang lahir dan menjadi lebih kuat nalar lahirnya.

Menurut Hamka, sesuai dengan perkembangannya, setelah abad ketiga Hijriyyah, timbullah berbagai aliran Tasawuf. Makna wali telah 
menyimpang dari makna awal. Makna wali Allah berubah menjadi manusiamanusia istimewa yang mempunyai derajat tinggi, dan berusaha atas seluruh alam ini, bisa menahan matahari, dengan isyarat menahan aliran sungai, bisa shalat jum'at di Masjid al-Haram setiap minggu.

Hamka tidak setuju dengan manakib yang konten ceritanya mendewakan dan mengkultuskan sufi, praktek ziarah kubur yang bid'ah, keyakinan bahwa ada orang yang kebal dari benda tajam dan racun dengan alasan Nabi merasakan racun yang ada di kepalanya sebelum ajalnya. Juga Abu Bakar masih merasakan sisa racun yang beliau terima pada perang Khaibar. Pemaparan Hamka tentang term ghauts, tingkatan wali dan jumlahnya di setiap masa dan tempat, Ibnu Arabiyyah adalah Khatim alAwliya, para wali mengatur kehidupan dunia melalui organisasi yang mereka namakan Dewan Bathin, Hal ini menunjukan pemahaman Hamka yang dalam terhadap teori-teori Tasawuf. ${ }^{67}$

Dalam penafsiranya pada surah Yunus ini, Hamka menyarankan apabila kita mendapatkan suatu kelebihan dari Allah maka janganlah kita minta kepadanya dan memujanya, tetapi mintalah langsung kepada Tuhannya. Hal ini memberikan pengertian bahwa Hamka menolak konsep tawassul dengan orang-orang sholeh.

Pada akhir pembahasan beliau menceritakan pengalaman pribadinya ketika masih menjabat pegawai di Depag tahun 1951. Beliau terkunci bersama temannya di kamar hotel. Dengan hanya membaca basmalah Hamka bisa membuka pintu secara paksa. Tahun 1959, beliau tidak digigit lipan yang sudah menempel dan merayap di badannya dengan alasan

\footnotetext{
${ }^{67}$ Hamka, Tafsir al-Azhar, juz XI, h. 251-263.
}

membaca doa ma'tsur dari Nabi. Di tahanan Sukabumi, penjaga sel menjadi tunduk kepadanya dan meminta doa yang biasa dibaca oleh Hamka. Keduanya mengurungkan niatnya untuk menyiksa Hamka dengan kabel listrik. Pada tahun 1964 - 1965, Hamka di penjara di Rumah Sakit. Selama dalam tahanan beliau khatam al-Qur'an lebih dari 150 kali, setiap malam bertahajjud, beliau mendengar hatif berkata "tujuh belas bulan engkau di sini". ${ }^{68}$ Namun penulis tidak akan menceritakan pengalaman Hamka seluruhnya dalam tulisan yang singkat ini.

\section{Konsep Mahabbah}

Mahabbah dalam persfektif Tafsir al-Azhar adalah cinta Tuhan yang dibalas oleh Hamba-Nya. Cinta ini semakin bersemayam dengan adanya memfokuskan pikiran kepada-Nya. Orang yang sudah mencapai derajat mahabbah akan memiliki perasaan yang tidak samar-samar lagi. Hijab denganNya sudah hilang. Rasa mahabbah, akan menimbulkan perasaan diri-Nya senantiasa menatapnya. Cinta sejati kepada Tuhan telah diajarkan Musa, yang berintisari pengorbanan. Sipatnya ialah jalal, kemuliaan. Nabi Isa, membawa lanjutan ajaran berdasar akan $h u b b$, cinta. Sifatnya adalah jamal, indah. Nabi Muhammad menyempurnakan penyerahan kepadaNya. Sifatnya adalah Kamal.

Hamka menjelaskan pula tentang makna cinta palsu. Yaitu cinta yang tidak disertai dengan kepatuhan. Cinta yang tidak mengikuti bimbingan Nabi. Maka ini adalah maghdub. Cinta yang direka-reka dan direncanakan sendiri maka ia dhalim. ${ }^{69}$

\footnotetext{
${ }^{68}$ Hamka, Tafsir al-Azhar, h. 268.

${ }^{69}$ Hamka, Tafsir al-Azhar, juz III, h. 218.
} 
Konsep Mujahadah: Studi analisis alAnkabut ayat 69

Allah memberikan jaminan kepada siapa saja yang menyediakan akan dirinya menempuh jalan Allah. Tujuan mereka hanya Allah. Semua rintangan dilaluinya hanya dengan tujuan menuju Allah. Mereka mengetahui bahwa jalan yang akan mereka lalui adalah sulit, tetapi mereka terus melangkahkan kaki seraya bekerja keras. Karena jiwa mereka ikhlas, telah terbuka, bertauhid dan berma'rifat, husnudzhan, maka selanjutnya Allah sendiri yang membimbing mereka. Mereka yang berbuat demikian adalah orang-orang muhsin yang senantiasa disertai Allah. Fudayl bin 'Iyad mempertalikan antara ikhlas dan Ihsan. Ikhlas ialah memperbaiki niat sejak semula agar beramal benar-benar karena Allah dan bersedia berjihad untuk itu. Ihsan adalah membuat amalan yang awal menjadi lebih baik dengan cara mengikuti Sunnah yang digariskan Nabi. Beliau memberikan I'tibar, bahwa Nabi yang ummi saja mampu melewati rintangan tersebut dengan baik bahkan beliau bisa mengajak umat untuk mengikutinya secara berjamaah. Seharusnya umat masa kini yang nilai intelektualnya lebih meningkat secara umum harus bisa mencapai apa yang telah dicapai Nabi dan para sahabat. ${ }^{70}$

Hamka tidak mendefinisikan term bashirah, nur, ma'rifat secara utuh sebagaimana apa yang didefinisikan oleh para praktisi Tasawuf. Beliau hanya mengartikan bashirah dengan makna leterlek saja, yaitu bukti-bukti. Tanpa mena'wilkannya sebagaimana yang telah terkonsep dalam Ilmu Tasawuf. ${ }^{71}$

\footnotetext{
${ }^{70}$ Hamka, Tafsir al-Azhar, juz XXI, h. 36.

${ }^{71}$ Hamka, Tafsir al-Azhar, juz XIII-XIV, h. 48. Qs. Yusuf : 108.
}

\section{Ilmu Ladunni}

$\begin{array}{lrr}\text { Dalam } & \text { tafsirnya } & \text { Hamka } \\ \text { mendefinisikan apa yang } & \text { dimaksud } \\ \text { dengan ilmu ladunni. } & \text { Beliau } \\ \text { mengartikan dengan ilmu } & \text { yang }\end{array}$ langsung dari Kami. Menurut Hamka, jiwa seseorang yang sudah berolah tazkiyah dari hawa nafsu, maka hatinya akan laksana kaca, bening tiada noda. Maka timbullah nur yang bersumber dari dirinya, dan akan menerima nur dari luar. Inilah yang disebut dengan nur 'ala nur. Maka ia akan bertambah dekat dengan Tuhan, ia menjadi derajat al-Muqarrabin. Dalam tingkatan demikian, maka ia akan mudah menerima ilmu dari Tuhannya. Baik berupa wahyu untuk Nabi maupun ilham untuk orang shalih. Orang yang demikian akan cepat dikenal sama orang yang selevel dengannya, ketika ia bertemu walaupun hanya sekali. Menurut Hamka, Sayyid Qutub tidak menafsirkan abdun shalih ini sebagai Nabi Khidir As. Menurut Sayyid Qutub, jalan ceritanya yang ghaib mengatakan sebaiknya cerita ini dibiarkan dalam keghaibannya tidak perlu ditambahtambah yang kadang telah bercampur dengan dongeng dan cerita Israiliyyat yang tidak bisa dipertanggungjawabkan.

Hamka mengakui bahwa ayat ini menjadi sandaran ahli Tasawuf dalam etika Murid dan Mursyid. Menurut Hamka, apa yang dialami Musa juga dialami oleh umumnya manusia, tentunya sesuai dengan tingkatan masing-masing yang dicapainya. ${ }^{72}$

\section{Penutup}

Al-Qur'an mempunyai kemukjizatan yang tidak dimiliki oleh kitab suci lainnya. Yaitu ajaranya

\footnotetext{
${ }^{72}$ Hamka, Tafsir al-Azhar, juz XV, h. 226.
} 
meliputi seluruh aspek kehidupan. Seorang mufasir yang mempunyai keahlian multidisiplin akan memberikan kesempatan kepadanya menggali kandungan al-Qur'an sebanyakbanyaknya. Walaupun pada hakikatnya kandungan al-Qur'an itu tidak akan pernah kering. Hamka adalah salah satu dari para mufassir tersebut. Pengalamannya dalam menyelami literatur-literatur Tasawuf secara otodidak dimanfaatkan olehnya untuk menginterpretasikan al-Qur'an dengan pendekatan Ilmu Tasawuf.

Dalam penelitian di atas, ternyata Hamka tidak mendefiniskan dan menjelaskan term-term Tasawuf secara menyeluruh. Nampaknya Hamka hanya mendefinisikan term-term yang dibutuhkan konteks sosial saja. Hamka belum merekonstruksi konsep Tasawuf secara holistik dalam perspektifnya sendiri. Akan tetapi hal ini bukan berarti Hamka tidak memberikan kontribusi sama sekali. Teori Tasawuf klasik yang didealektikakan dengan konteks sosiokultural masyarakat modern Jawa dan Melayu adalah sebagian apa yang diberikan beliau untuk kajian Tasawuf.

Namun demikian, aspek Tasawuf dalam tafsir al-Azhar ternyata tidak mempengaruhi kesimpulan penelitian sebelumya yang menyatakan bahwa corak tafsirnya adalah Adabi Ijtima' $i$ dengan membawakan karakter-karakter khusus yang disesuaikan dengan konteksnya. Juga metodologi (thariqah) yang dipakai dalam penyampaiannya adalah metodologi tahlili. Adapun manhajnya adalah tafsir beliau ini menggabungkan antara validitas naql dan kekuatan akal, akan tetapi prosentase kekuatan akal lebih dominan sehingga dikategorikan sebagai Tafsir bil Ra'y.

\section{Daftar Pustaka}

Al-Qur'an al-Karim

Abdullah, Mustafa "Sayyid Muhammad Rashid Ridha's Influences on Tafsir Studies in Malaysia," Middle-East Journal Science Researshes 12, no. 6 (2012) : 762.

Alwi, Shihab. Membendung Arus: Respons Gerakan Muhammadiyyah Terhadap Penetrasi Misi Kristen di Indonesia. Bandung: Mizan, 1998.

\section{Bandung: Mizan, 2001.}

Azra, Azyumardi Islam Substanstif: Agar Umat Tidak Jadi Buih. Mizan: Bandung, 2000. dan Saiful Umam (ed). Mentri-Mentri Agama RI: Biografi Sosial Politik. Jakarta: Indonesia-Netherland Cooperation in Islamic Studies (INIS). Pusat Pengkajian Islam dan Masyarakat (PPIM). Badan Litbang Agama Depag RI, 1998.

Jaringan Ulama Timur Tengah dan Kepulauan Nusantara Abad VII dan VIII. Jakarta: Kencana, 2013.

Abdullah, Mustaffa, Faisal Ahmad Shah, Ishak Suliaman, Mohd, Yakub Zulkifli Mohd Yusoff, Monika Munirah Abd Razzak, Fauzi Deraman, Khadher Ahmad, Mohd Murshidi Mohd Noor, Jilani Touhami Meftah, Sedek Ariffin, Ahmad K. Kasar, Selamat Amir, Abu Zayd, Nasr Hamid. Falsafat al-Ta'wil: Dirasah fi Ta'wil al- 
Qur'an 'Inda Muhyi al-Din bin Arabi. Beyrut: Al-Markaz alThaqafi al - Arabi, 1996.

Atsushi, Ota., Okamoto Masaaki, dan Ahmad Suaedy (ed), Islam In Contention : Rethinking Islam and State in Indonesia. Jakarta: Wahid Institute - CSEAS-CAPAS, 2010.

Bruinessen, Martin Van and Julia Day Howell (ed), "Sufisme and Modern In the Islam", London and New York, I.B. Tauris (2007) : 229.

and Julia Day Howell (ed), "Sufisme and Modern In the Islam" London and New York, I.B. Tauris (2007) : 241.

Djamal, Murni. DR. H. Abdul Karim Amrullah: Pengaruhnya Dalam Gerakan Pembaruan Islam di Minangkabau pada Awal abad ke20 (Leiden-Jakarta: Hak Cipta INIS, 2002), 20.

Ernst, Carl W,. Ajaran dan Amaliah Tasawuf. Jogjakarta: Penerbit Pustaka Sufi, 2003.

Faisal, Ahmad, Abdul Hamid and Mohd Roslan Mohd Nor, "Sayyid Muhammad Rasyid Rida's Influence on Tafsir Studies in Malaysia”. Kuala Lumpur: Middle-East Journal of Scientific Research 12, no.6 (2012) : 6. Versi PDF .

Federspiel, Howard M. A Dictionary of Indonesian Islam. Ohio: Center For International Studies Ohio University, 1995.
Ghafur, Saiful Amin. Profil Mufassir al-Qur'an. Yogyakarta: Pustaka Insan Madani, 2008.

Harun, Salman. Mutiara al-Qur'an. Ciputat: Logos, 2004.

Hashim, Rosnani (ed), "Hamka Intellectual and Social Transformation of the Malay World", in Conversation Islamic Intellectual Traditionin the Malay Archipelago, ed. Rosnani Hashim. Kuala Lumpur, Pustaka Perdana, 2010.

, "Hamka Intellectual and Social Transformation of the Malay World", 226. "Ethnic Relation: Some Related Editorial Issues" Malaysia, Medwell Journal: The Social Science 7 (4) (2012) : 557559.

Hobat Habbatussauda, "Kisah Sederhana Antara Buya Hamka dan KH.Abdullah Syafi'ie", 19 September 2011. https://www.facebook.com/notes/ hobat-habbatussauda/kisahsederhana-antara-buya-hamkadan-khabdullahsyafiie/263017877065461?ref=nfa 1-Hujwiri. Kashfuln Mahjub. Mesir. al-Kitab al-Tisun, 1974.

Jalil, Muhammad Hilmi dan Fakhrul Adabi Abdul Kadir, "Written Works As A Channel of Human Development: Studies On Hamka's Novel". IJRESS. Volume 2. Issue 5 (Mei 2012) : 2.

Al-Khalidi, Shalah Abdul Fattah Tafsir Metodologi Pergerakan. Jakarta: Yayasan Bunga Karang, 1986. 
Ken'ichi, Goto. "Modern Japan and Indonesia The Dynamics and Legacy of Wartime Rule" Leiden, Bijdragen tot de Taal-, Land- en Volkenkunde, Japan, Indonesia and the WarMyths and Realities 152. no: 4 (1996) : 536-552.

Majid, Nurcholis. Tradisi Islam: Peran dan Fungsinya Dalam Pembangunan di Indonesia Dian Rakyat dan Paramadina: Jakarta, 2008.

\section{Islam Kemodernan} dan Keindonesiaan. Bandung: Mizan, 1998.

Nizar, Samsul. Memperbincangkan Dinamika Intelektual dan Pemikiran HAMKA tentang Pendidikan Islam. Jakarta: Kencana, 2008.

al-Qushayry, Abi al-Qasim Abd alKarim bin Hawazin al-Risalat alQushayriyyah. Damsyik: Maktabah al-Imam al-A'dzam Abi hanifah dan Damsyik: Maktabah al-Ilm al-Hadits, 2000.

Rashid, Zuriati ibn Muhammad "AlFaruqi and His Views on Comparative Religion "International Journal of Business and Social Science 1, no. 1 (2010) : 1 .

Riddel, Peter. Islam and The Malay Indonesian World. Singapore: Horizon Books, 2001.

Shihab, Quraish. Rasionalitas alQur'an. Jakarta: Lentera Hati, 2006.
Sulasman, "Kyai and Pesantren in the Islamic Historiography of Indonesia", International Journal for Historical Studies 4, no.1 (2012) : 67, 71-72.

Tim Penulis UIN Syarif Hidayatullah. Ensiklopedi Tasawuf. Bandung: Angkasa, 2008.

Ya'kub, Zul'azmi 'Falsafah Alam dan Konteks Falsafah Ketuhanan Menurut Hamka," International Journal of Islamic Thought. Vol.1 (June 2012) : 2.

\section{Yusuf, Yunan. Corak Pemikiran Kalam Tafsir al-Azhar. Jakarta: Permadani, 2004.}

Zulkifli. The Strugle the Shi'i In Indonesia. Leiden: University of Leiden, 2009. 